\title{
SOME PROBLEMS OF COELENTERATE ONTOGENY
}

\author{
CHARLES W. HARGITT \\ From the Zoological Laboratory, Syracuse University \\ THREE PLATES AND THREE TEXT FIQURES \\ CONTENTS
}

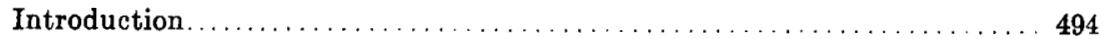

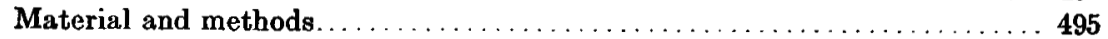

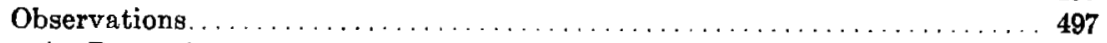

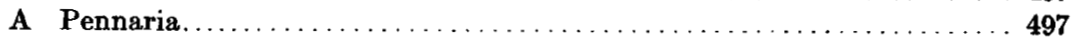

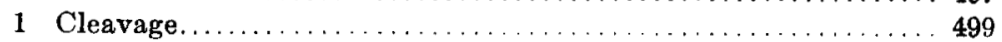

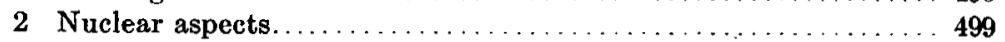

3 Amitosis.................................... 501

B Hydractinia echinata Flem.................... 502

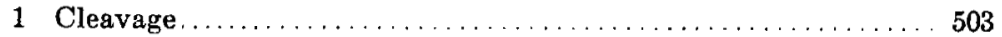

2 Ectosarcal features.............................. 508

3 Early embryo, morula ......................... 508

4 Organization of the embryo....................... 509

5 Entoderm formation. . . . . . . . . . . . . . . . . . . . . . . 509

6 The larva, planula ............................. 510

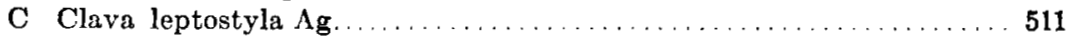

1 Maturation............................ 511

2 Nuclear behavior ................................ 512

3 The chromatin................................. 513

4 Nucleolar behavior .................................. 516

5 Later development.............................. 517

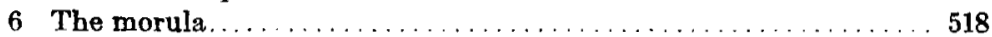

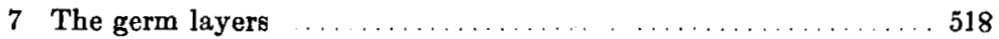

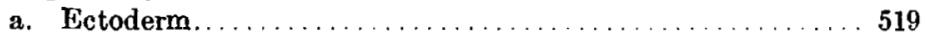

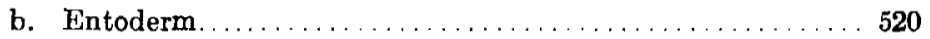

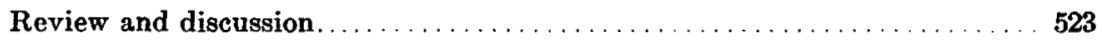

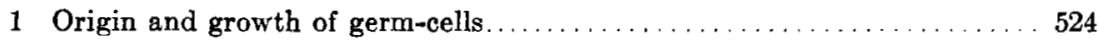

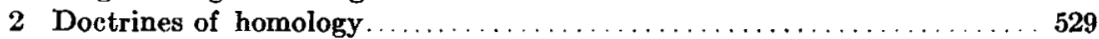

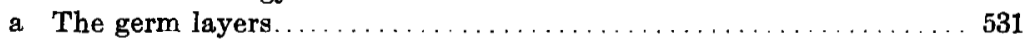

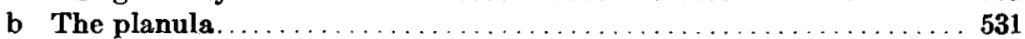

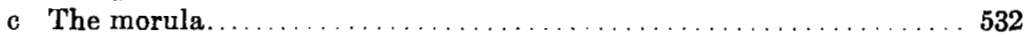

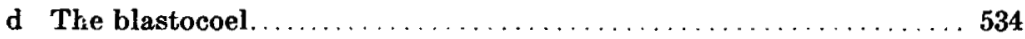

e Cleavage homology ..............................535

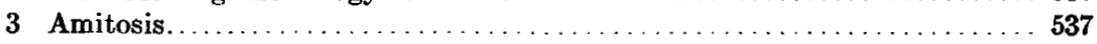

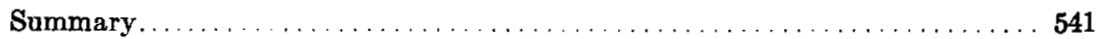

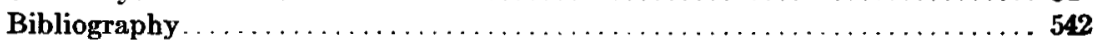

JOURNAI OF MORPHOLOGY, VOL. 22, NO. 3 SEPTEMEER, 1911 


\section{INTRODUCTION}

In the course of investigations carried on by the writer during several years, certain facts have come to light which seem to have important bearings upon several problems of general ontogeny. In various papers phases of these have been suggested, but only incidentally has any attempt been made to discuss their significance or their probable correlations as developmental phenomena. With further investigations still additional facts have been observed, and similar investigations by others have tended to convince me of their importance in a still larger degree. When the honor to coöperate in the preparation of this memorial volume was submitted, it seemed that no more appropriate subject came within the scope of the writer's researches than that involved or implied in the above caption.

My introduction to coelenterate morphology began many years ago with the problem of the origin of sex-cells, a subject at that time brilliantly exploited by Weismann, whose "Entstehung der Sexualzellen bei den Hydromedusen, Zugleich ein Beitrag zur Kentniss des Baues und der Lebenserscheinungen" ('83), has long been a recognized classic in its line. It was ably supplemented by the hardly less brilliant researches of Metschnikoff ('86), "Embryologische Studien an Medusen. Ein Beitrag zur Genealogie der primitiv Organe."

The first contribution to the subject by the writer was a very brief and tentative paper before Section F, of the American Association for the Advancement of Science, in 1889. It was adversely commented upon by one who had accepted without question the then prevalent dogma that Hydrozoa were distinguished from all other Cnidaria by the origin of the sex-cells exclusively from the ectoderm. Under this adverse criticism no further utterance was made on the subject for several years, though there was no lapse of interest or investigation.

In the meantime, an observer here and there had dared to question the conclusiveness of the earlier dogma. Little by little facts were accumulating which cast further doubts upon the matter, and even compelled the conclusion that Weismann's 
fundamental contention was inconclusive. Results to be cited from various sources will tend to show that the early attempt to formulate a general theory of embryogeny on the basis of the origin of sex-cells was no less defective and inadequate than it was hasty.

For some time past phases of my researches have forced the impression, which has deepened as the investigations have extended, that not a few of the earlier views as to coelenterate ontogeny were seriously defective, or absolutely in error at many points. Certain of these I have taken occasion to point out from time to time, as occasion arose. The purpose of the present paper is two-fold: First, to submit accounts of the development of several species of Hydromedusae which have been under investigation for some time; and secondly, to point out certain errors as to the ontogeny of the groups which, from various reasons, had become associated therewith.

\section{MATERIAL AND METHODS}

1. Material. The material upon which the results herein described are based (with the exception of that of Pennaria australis, for which I am indebted to Mr. Edgar J. Bradley, of Australia, to whom my thanks are hereby acknowledged) was collected by the writer at various times within the past two years, and chiefly in the immediate vicinity of Woods Hole, though some of that of Clava was collected at Harpswell, Maine. It is a pleasure to express my thanks to the directors of these laboratories for various courtesies.

Attention will be given primarily to two species of Pennaria, and to a single species each of Clava and Hydractinia. Other species will be given attention in relation to the several problems with which the paper has to do.

2. Fixation. In my earlier work great difficulty was encountered in reference to killing and fixing reagents. For killing my first lots of eggs of Pennaria picro-nitric and picro-sulphuric solu-. tions, then much in vogue, were used; but to my sorrow these were found to be almost worthless. This was particularly the case with picro-sulphuric. Almost the whole of one summer's 
collection was absolutely worthless by reason of the almost exclusive use of this reagent.

Hermann's and Flemming's solutions afforded fairly good fixation, but subsequent staining was very difficult. Perenyi's solution was absolutely worthless with both Eudendrium and Pennaria material and has since been discarded. The only solution which gave reasonably good and fairly constant results was a strong solution of corrosive sublimate to which had been added 5 per cent of glacial acetic acid.

In later work I made use of various solutions of formaldehyde, but with only fair results. A 10 per cent solution in sea-water gave a good general fixation for immediate use. Combination with corrosive did not seem materially to better it. There was found also to be great variability in different species as to this matter. This was particularly apparent in eggs heavily yolk laden as compared with those in which yolk was lacking, or present in only small quantities. There was also great difference in later differentiating other cytoplasmic elements. For example, in the peculiar proteid granules present in eggs of Clava the first, and only satisfactory reagent was picro-acetic acid (p. 217, Biol. Bull., vol. 10, '06).

In 1906 my attention was directed to Bouin's picro-aceticformol. It was thoroughly tested upon eggs of Pennaria and Hydractinia, and was found to be far superior to any thus far employed. I have since used Zenker's fluid with good results in fixation of eggs of several species. It is worth while to emphasize the importance of this feature of fixation, especially as it relates to coelenterate material. I have called attention to this in several previous papers, but it is absolutely imperative in order to warrant trustworthy results that particular attention be given to this matter.

3. Imbedding. In another respect I have learned to my cost the importance of prompt working up of coelenterate material after fixation. Attention was directed to this point in my paper on Pennaria ('04b, p. 455). This precaution has been abundantly confirmed by later experience, and I take occasion here to emphasize its importance once more. The value of this has been 
vouched for by Smallwood ('09). My present method in this particular is to imbed the material in paraffine as early as possible after reasonable time has been given for proper hardening and dehydration. This imbedded preservation may apparently be indefinitely prolonged without detriment. But in my experience it is impossible to preserve material of this group for any considerable period in alcohol without having it suffer considerable deterioration. This is particularly the case with those cytologic factors of mitosis and allied features so important in modern problems of embryology.

4. Staining. This, like the matter of killing and preservation is one of much importance and of varying grades of diffculty, as it related to the problem under review. As in the preceding, I had long since called attention to the extreme difficulty in the staining reactions of coelenterate material. This was most marked, in my experience, in the eggs of Eudendrium and Pennaria. Others have also found similar difficulties with this phase of technique. G. T. Hargitt ('09, p. 163) has recently devoted some attention to the subject, and my own results have been confirmed by those described in his paper.

Difficulties experienced in my earlier work in Pennaria, and the later work on Clava, were such as to leave doubt, particularly in relation to the phenomena of maturation, leading me to conclusions, tentatively adduced, which subsequent work has not confirmed, as shown by G. T. Hargitt (op. cit.) and Smallwood ('09), and by facts herein described.

\section{OBSERVATIONS}

\section{A. Pennaria}

Except for additional facts which have come to light in relation to a species of Pennaria, the development of which has been hitherto unknown, no particular attention would be given to the subject in this connection. Since the issue of my detailed paper on the early development of Pennaria tiarella ('04), repeated observations on the living eggs have confirmed my previous 
results in every detail, so far as the general facts are concerned. I think it may now be regarded as beyond doubt or cavil that these results, anomalous as they may appear, are absolutely normal and conclusive. Furthermore, when analogous cases to which I had directed attention, and others to be cited in a later connection, are taken into consideration, it seems rather strange that "early cleavage differing widely from what we have come to think as typical" should be given as adequate grounds for a reëxamination of the case! However, when it is recalled that, with certain investigators, it is more important to reduce vital phenomena to a set of formulae, or to corral all development within a common law than to recognize facts as they are, the wonder is less strange than it might at first seem! But additional facts are now available from a most unexpected source, and of such character as to remove any further grounds for question or doubt.

Somewhat over a year ago I had the good fortune to receive from Mr. Edgar J. Bradley, of Adelaide, Australia, a collection of hydroids, and along with them several colonies of Pennaria australis Bale, together with the medusx and eggs, which had been taken in tow-nets just at the height of the breeding season. The only feature of regret as to the eggs is that they had not been preserved in other than weak formalin, in order to have made them available for cytological study. But, as it is, they show in surface study the external aspects of developmental behavior to such perfection as to leave little to be desired. Figures 5 to 8 are sketches of a few of these stages, which speak for themselves. As will be seen at a glance, they duplicate in a most striking way similar stages in the development of Pennaria tiarella. If one were to pass under review separate series of eggs of the two species, without pains to have critically determined them in advance, it would be practically impossible to say which belonged to the one species and which to the other. There are the same ectosarcal features,- papillæ, bridges, strands, etc., in both; the same bizarre, amoeboid characters, the same anomalous phases of cleavage, 'every egg a law unto itself', and finally the same end resultant, a normal embryo. Later phases of development of the Australian species were not present, hence further compari- 
son was impossible, though there is no reason for doubt as to its subsequent similitude and results. A comparison with figures 1 to 4 , of Pennaria tiarella, will make this more evident.

The fact that these eggs had been taken with the tow-net in the open harbor, and had been preserved shortly after in formalin, leaves no grounds for serious question as to their normal condition, and confirms completely the results of my own precautions ('04b, p. 474), to guard against possible effects of artificial conditions of the laboratory. These additional facts, together with others of like character which have since come to our knowledge, especially those described by Brooks and Rittenhouse ('07) must suffice once for all to establish the perfectly natural and normal phenomena of extremely erratic and indeterminate modes of cleavage and consequent organogeny.

1. Cleavage. There is nothing new to add concerning the cleavage features of the eggs of Pennaria tiarella. Concerning this feature in Pennaria australis little attempt will be made to give detailed descriptions. The figures cited will afford all that is necessary as to the general surface aspects. As already stated, there is such essential conformity in every respect to the corresponding stages in Pennaria tiarella that there seems small occasion to do more than refer to the figures and descriptions of the former paper ('04b). While the fixation does not give material fit for cytologic details, it is fairly good for general comparisons. Eggs carefully stained and cleared show fairly well the general internal conditions, and here, as in the surface features, there is essential likeness to corresponding stages in Pennaria tiarella.

2. Nuclear aspects. Brief reference may be made to a few points under this head.

Fragmentation. In several of my eaplier papers ('04b, pp. 460-1), attention was called to certain nuclear phenomena of a rather peculiar character. Among these was what seems to be a rather piomiscuous dissolution, or disintegration of the nucleus and the dispersion of the greater portion of it into the cytoplasm. To designate this process I used the term fragmentation, long previously employed to designate phases associated with direct nuclear division. and apparently first employed by Van Beneden (Wilson, the Cell, p. 64). 
In recent papers both Smallwood ('09) and G. T. Hargitt ('09, pp. 197-8), have expressed doubt as to the process in the eggs of Pennaria, the latter stating that "no sign of its fragmentation has ever been seen." But in the following sentence he adds, "the supposed disappearance of the germinative vesicle at this time, I believe to be due simply to the usual dissolution of the nuclear membrane and the mingling of karyoplasm with cytoplasm."

Smallwood expresses similar doubt, saying:

If by fragmentation of the nucleus is meant that the entire nucleus disappears and its contents disperse throughout the cytoplasm, then I find no evidence of such a process in these hydroids. But what shall be said of the chromatin changes before maturation in Hydractinia and in Pennaria after maturation, where large quantities of chromatin migrate into the cytoplasm? (Op. cit., p. 228.)

It was chiefly in this latter sense that I had used the term. and observations of Coe, Lillie, and others were cited in support of facts found in Pennaria. It may also be admitted that there seemed to be evidences of the entire dispersal of nuclear substance through the cytoplasm and their subsequent reorganization into new nuclei. ('06, p. 227, etc.). Further reference to this will be made in another section.

Contention for fragmentation was based almost wholly on chromatin behavior. The facts which I urged in this connection were those involving, first, the enormous dissipation of chromatin and its absorption by the cytoplasm, during the phases of maturation; and secondly, the achromophilous condition of the chromatin at a slightly earlier time. These facts have not been disputed. Whether my inferences or interpretations are valid is quite another matter. As to that upon which I have laid most stress, viz., the disintegration and dispersal of a preponderating portion of the chromatin, certainly not less than $\mathbf{9 0}$ per cent in many cases, and that it has little or no subsequent function as chromatin, -I am still firmly convinced of its validity and of the vast significance it involves as to chromosome theory.

Concerning the achromophilous condition above referred to, I have little to add to my previous accounts. G. T. Hargitt 
('09, p. 165), whose detailed experiments on differential staining have surpassed my own, was perplexed as to this condition. "At the end of the growth period, the nuclear reticulum shows so little affinity for basic stains that there appears to be, so far as this test shows, no chromatin present in the entire nucleus. I can suggest no explanation for this peculiar condition of the chromatin at this period, but it is normal and characteristic of this stage." I am now convinced that there is here a chief ground for my failure to distinguish certain phases of maturation, and my subsequent error in the assumption of their possible suppression or modification in certain cases.

3. Amitosis. Concerning a further problem, that of amitosis, I am in doubt so far as Pennaria is concerned, even as at the time of my previous work. My chief grounds for this view are the facts first cited, and those of the multivesiculate aspects of the nucleus during cell proliferation. And here again Smallwood and G. T. Hargitt ('09), and later Beckwith ('09), all confirm my basis of facts. They find in these vesiculate nuclear conditions essentially the same results which are described in my accounts. Without exception their interpretations differ from mine. To them these facts are believed to be obscure phases, chiefly telophases, of mitosis. While I freely admit the force of their contentions, there are still good reasons for maintaining the plausibility of my own views and interpretations. This is especially the case concerning Eudendrium. Here there seemed to be clear and positive examples of amitosis, as shown in fig. 23, $a$ and $b$, plate 15 ('04a). It may not be amiss to state here that all these examples of amitosis occurred in association with those 'nuclear nests' so intimately involved in the syncytial phase of development concerned in entoderm formation. The conditions are somewhat different in Pennaria, yet sufficiently similar to lead one to anticipate similar processes, and these appeared probable in the vesiculate 'nuclear nests' mentioned above. But in no case were there found the specific and positive examples figured in the case of Eudendrium. The same must also be said of Clava. But further discussion of this will be reserved for a later section. 


\section{B. Hydractinia echinata Flem.}

During the summer of 1907 I was fortunate in securing large numbers of this hydroid in the height of its breeding season, and took occasion to study the development and life history of the species. Some account of the life history has already been given ('08) which obviates any call for emphasis here on this point. The early development was studied from living material during two summers and at the same time material was carefully preserved for cytological study. This latter was turned over to my colleague, Dr. Smallwood, and his results have already appeared ('09). It only remains for me to submit such accounts of my observations as seem important in order to afford a more or less complete and connected description of phases of development, especially when correlated with Smallwood's account referred to above.

There are numerous points of difference between my observations and those of Bunting ('94), some of which may be due to the fact that her studies were restricted to material obtained from the small colonies living upon shells occupied by hermit crabs, while my material was derived chiefly from colonies of enormous size, obtained from piles of docks or similar habitat, but with comparison from the former sorts. As pointed out in the paper referred to above ('08, p. 98), there is no adequate reason for regarding these hydroids as other than a single species, hence any differences to be cited must be incidental rather than fundamental.

One of the first points of difference to be noted is concerning the time at which the liberation of sexual products takes place. According to Bunting this is between the hours of $9: 30$ and $10: 30$ P. M. That it occurs during the night I have repeatedly demonstrated. Further, that it may occur in certain cases about the time stated by Miss Bunting, I have also found true. But that it may also occur at a much later hour, and also at varying hours, I have also found to be the case. Some of the best cleavage series obtained, especially for the very early stages, were in the mornings from seven to nine o'clock. That is to say, the eggs had been deposited some time after midnight, and at the hours 
named were in early stages (two- to eight-cell) of cleavage. This would seem strongly to indicate their deposition at perhaps five or six o'clock in the morning or thereabout, as recorded in my notes of July 11th and 12th. In other cases development had reached the morula stage at nine A. M., which would lead to the conclusion that liberation of sexual products had occurred about midnight. While it is true that in many hydroids the liberation of eggs and sperm occurs at a fairly constant time, yet there are others in which this is not the case, and in which such ripening and discharge is a more or less continuous process during the breeding period.

The character of the egg is much like that of Pennaria, though it is much smaller. Both are alike in general texture of protoplasm, contain yolk, and similar inclusions. There is present a pigment similar to that in the eggs of Pennaria, though less marked in color. Like those of the latter, the eggs are devoid of a definite membrane. They are rather heavy and sink promptly when set free. By reason of this it was practicable to suspend colonies in shallow vessels within wire baskets under docks in freely circulating water and with little liability of their being lost. This was a matter of some importance; for, despite the best precautions, these hydroids soon deteriorate in vitality under the artificial conditions of the laboratory, while by suspending them in open waters about the docks they thrive almost as if in the natural habitat.

1. Cleavage. So far as I am aware the only definite work on cleavage of Hydractinia is that of Bunting ('94). In this paper we have a characteristically symmetrical portrayal of the process. In generai surface aspects it is represented as almost mathematical in its regularity and symmetry.

That the earlier cleavage phases in perhaps a majority of the eggs conform to this in greater or less degree is probably true. But that it represents with any degree of accuracy the average behavior of this phenomenon as a whole none who had carefully followed it could for a moment admit. It has been difficult to conceive how, except by a selective process, any such account could have been formulated. It is quite easy to see that by directing 
attention only to eggs which exhibited the regulation aspects of cleavage, and disregarding, as abnormal, those of differing aspects, just such an account might easily have been made up; and this in all probability may have been the method followed.

It is not strange that under prevailing conceptions as to formulated 'laws of cleavage' this method might naturally have been adopted. In the case of Pennaria the present writer deliberately disregarded an entire batch of eggs which were so erratic in behavior as to suggest the probability of pathological conditions. But, by whatever method one may explain the matter, certain it is that there is a measure of irregularity in a large proportion of the eggs of Hydractinia, especially after the third or fourth cleavage furrows, which at once takes them out of the usual category of geometrical order or symmetry and puts them, if not in the Pennaria class of chaotic irregularity, at least consigns them to the category of the indeterminate and unsymmetrical.

However, it is not my purpose, in thus discrediting an account which gives so inadequate and misleading an impression, to go to a similar extreme in the other direction and convey the impression of predominantly erratic cleavage. On the contrary, let it be noted that in perhaps a majority of the eggs of Hydractinia echinata the cleavage, while seldom exhibiting an approach to geometric order or symmetry, is yet more or less regular and orderly. In such cases cleavage begins, as usual, at the animal pole, cutting vertically downward, and generally divides the egg into symmetrical halves, which adhere to each other by a narrow band, or connective of cytoplasm at the lower pole. The second cleavage likewise may begin at the upper pole and at right angles to the previous division, or may begin at the center and work outward, thus dividing each half into symmetrical fourths, giving a fairly typical four-cell stage. The third cleavage, which is usually equatorial, often begins at the center and extends toward the periphery, a process more or less common in eggs of hydroids. The subsequent phases may coritinue more or less orderly as in earlier stages, but often grow increasingly irregular and independent, though resulting in a symmetrical embryo. On the other hand, figs. 14 to 22 , which are camera sketches of living eggs, 
show how strikingly irregular and unsymmetrical cleavage may be in eggs of a given lot, developing under identical conditions. But in these cases the first two or three cleavage furrows are more or less symmetrical. In not a few, however, cleavage is distinctly erratic from the first, the first furrow dividing the egg into very unequal portions. In such cases the irregularity becomes usually increasingly more so as cleavage goes forward.

A very interesting case is that shown in figs. 9 to 13 , which occurred at irregular intervals within a period of about forty minutes of constant observation during which the sketches were made. The egg was kept under observation for several hours, or till the morula was apparently completely formed. Fig. 9 shows what may be regarded as a four-cell stage, the central portion comprising the main body of the cell, while at opposite poles are three other blastomeres, in each of which the nuclei were distinctly visible. In fig. 10 the small blastomere at the upper pole has divided, so that now we have a five-cell stage. It remained in this condition about fifteen minutes, when a most curious thing happened, the small blastomeres, $x$ and $y$, being the factors of most interest. At first the blastomere $y$ became detached from its connection with the cell body as shown in the figure, and later the other blastomere $x$ did the same thing, both thus becoming absolutely free, in which condition they continued about thirty minutes. At the end of this time they resumed division and went forward to complete segmentation and formed what seemed to be a perfect, though very small morula, shown in fig. 11, b. The other portion exhibited something of the same tendency. For example, the small blastomere $z$ cut itself free as had $y$, but it later drew back and, fusing with the cell body, continued as an integral part of the egg in its later development. Figs. 12 and 13 show the general aspects of this portion, which went forward normally and became a perfect morula and later gave origin to a normal planula. The small segment exhibited the same aspects, but later in the day began to show signs of degenerative tendency and finally disintegrated entirely without assuming the larval condition. This can hardly be ascribed to its minute size, for other embryos, which were otherwise apparently similar in every way, suffered the same fate. 
Among the anomalous aspects of cleavage which I have encountered in the development of these and other hydroid eggs not the least singular or significant is the occurrence, now and then, of what may be designated as blastomeric autotomy. That is to say, occasionally one finds during the earlier stages of cleavage, most commonly at the first, the complete separation of the primary blastomeres, which continue to develop as independent eggs, and from which independent embryos arise, giving origin to two polyps. I have called attention to something of this in Pennaria. The same thing has been found in at least two cases in Hydractinia. In one case actually followed from beginning to end the sequence of events may be briefly described. At the first cleavage of an egg which was in a marked degree unequal, the two blastomeres separated entirely, each part developing quite apart, and in a perfectly independent fashion. One of these segmented in a fairly regular and symmetrical fashion, while the other portion was markedly irregular from the first. It should be observed that the rate of cleavage in the former was much slower than in the latter, which exhibited a marked tendency toward amoeboid aspects as shown in the figures already cited.

It seems perfectly clear, therefore, that we have in these aspects of development a perfectly normal, and not particularly rare mode of segmentation, involving the origin of two, and probably even three or more embryos from a single egg, in a perfectly natural and spontaneous way.

Among these anomalous aspects, which were numerous as well as various, those shown in text figs. $A, B$ and $C$ will be interesting. In this case the first cleavage was about normal, beginning at the animal pole and extending downward to the lower, where the blastomeres remained attached by the connective shown in fig. $A$ for some time. The second cleavage was the not unusual type shown in fig. $B$ where it was directed centrifugally and in a horizontal instead of a vertical plane; and as it continued the connective was resorbed, leaving the two blastomeres quite free for a time during which they moved into the position shown in the figure, when the vegetal blastomere of the one side came into contact with the animal blastomere of the opposite part, in which posi- 
tion they fused and remained for some time. Fig. $C$ shows the condition when the four-cell stage had been established. As will be seen, the blastomeres had rotated until they became, as it were, fitted into close contact with each other, and the development of another connective bound them in that relation for some time. It may be noted that later development went forward with average regularity.

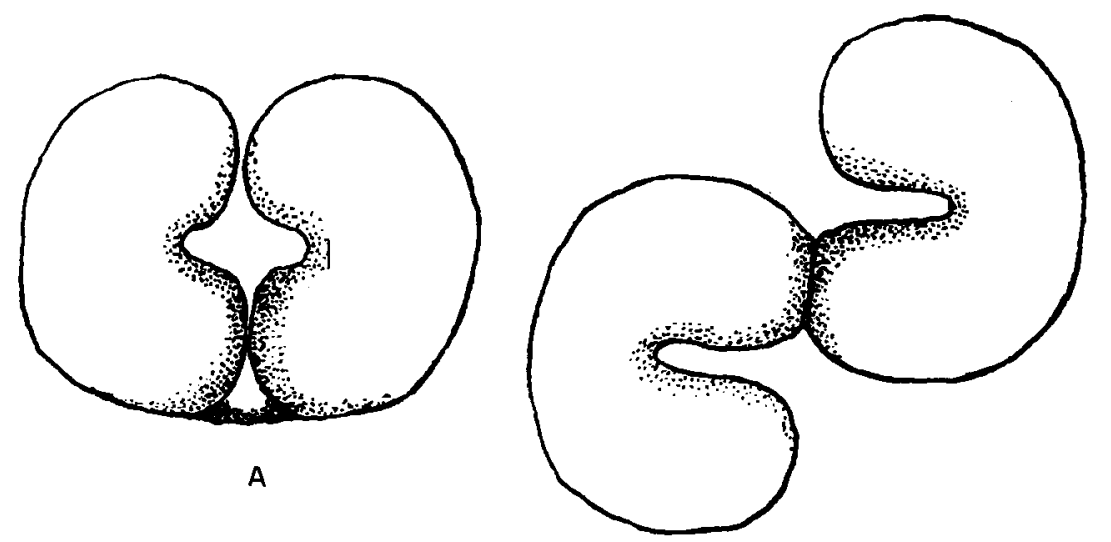

B

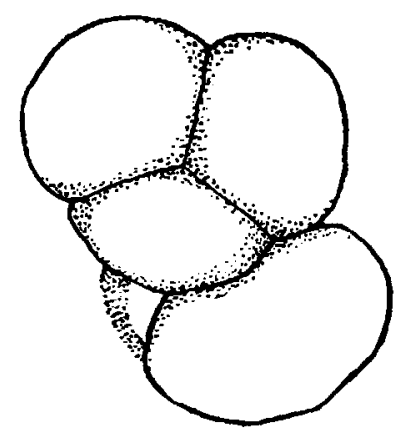

C

2. Ectosarcal features. In my paper on Pennaria ('04b, p. 469) attention was directed to certain very conspicuous aspects which were designated as 'ectosarcal phenomena' and which comprised various more or less superficial excrescences, such as papillae, films or bridge-like connectives between blastomeres, 
etc. They were described in some detail and various suggestions and comparisons submitted as to their significance.

In the eggs of Hydractinia very similar structures were encountered, though less conspicuous and less constant than in Pennaria. Certain of these are shown in figs. 14 to 22 . As to their significance or function I have nothing new to offer beyond that previously suggested. Their more obvious function would seem the two-fold one of connecting adjacent blastomeres, and affording coördinating bonds for the entire egg during development. These suggestions could hardly apply to the papillose structures of the surface, and their presence must be regarded as problematical.

3. The early embryo, morula. With the progress of cleavage toward completion the irregularities of surface, due to ectosarcal structures above mentioned and erratic cleavage, which were so conspicuous a feature, gradually disappear and the embryo tends to become more or less typically spherical and blastula-like. But in comparatively few Hydrozoa does a typical blastula occur. In my earlier accounts of the development of Eudendrium and Pennaria attention was directed to the presence of a true morula as the embryonic stage resulting from cleavage, and also to the entire absence of a stage comparable to a coeloblastula. This is likewise the condition to be found in Hydractinia and Clava. Rittenhouse ('07) has shown the same to be the case in Turritopsis nutricula. It will be shown in a later connection that this is the dominant type of cleavage embryo throughout the entire phylum. At no time is there to be found in either Hydractinia or Clava a distinctive or permanent cleavage cavity, though there may often be found certain intercellular spaces which are designated as such, but the correctness of which may be seriously challenged. This, again, will be considered in more detail in a later section.

For some time following the apparent completion of cleavage and the establishment of the morula there seems to be a period of quiescence. This is such, however, only in appearance; for in reality there exists a condition of active cell proliferation, as may easily be demonstrated by means of sections of embryos at this time. This has been especially demonstrated and emphasized 
in the cases of Eudendrium and Pennaria, but is no less true in the present instances.

4. Organization of the embryo. This has usually been assumed to consist fundamentally in the formation of the tissues, ectoderm and entoderm. In part this assumption is correct, but only in part. For example, the morula may remain for some time entirely devoid of these tissues in any definitive sense, and even in the later larval stage the entoderm may not arise till a late period. As has long been known, among the first evidences of organization is that associated with the formation of the ectoderm. Indeed, this is only what might naturally be expected as one comes to consider the primary function of such a tissue, or its analogue, throughout the animal kingdom. The embryo, no less than the adult organism, requires superficial protection against external conditions. And from protozoon to mammal provision is made to this end by ectosarc and epidermis, and in the embryo by the ectoderm, which may be regarded as the primary tissue of the embryo.

5. Entoderm formation. But up to this time there is no definite differentiation of entoderm. It is true, that one will find what has long been designated as entoderm, namely, an interior mass of embryonic matter more or less cellular, but without differentiation of any sort. By some students of hydroid development this condition has been described as the 'end of entoderm formation' (Ende der Entodermbildung). In reality one may better designate it as the beginning of entoderm formation, though even this might be open to question. What we have at this time is simply an interior embryonic mass, often a syncytium, within the enclosing ectoderm, if this be yet differentiated; and of this mass but a very small proportion ever participates directly in entoderm formation. For the sake of clearness it seems desirable formally to recognize this condition by giving to it such name as may express the fact, and at present no better term seems available than 'pro-entoderm.' This only implies the existence at this time of material, a primordium, out of which in varying ways will be developed the definitive entoderm of the larva. 
6. The larva, planula. The life history of the morula is comparatively brief, perhaps from six to eight or ten hours, the period varying considerably. During this time the definitive ectoderm has been established, cilia developed and the free-swimming larva, the planula, begins its career. Concerning the structure of this organism there is no occasion for special details. It differs little if at all from that characteristic of others whose structure has been repeatedly portrayed, and is too well known to need further account. In the present instance, as in those of numerous others, at the time of the assumption of this condition the larva is still a solid mass, with little organization beyond the above mentioned ectodermal differentiation. A definitive entoderm may not become established till relatively late in larval life, as I have repeatedly pointed out in other cases, and only after a process of physiological differentiation, as shown in a later section. The first evidence of a coelenteron appears as a slit-like cavity in the larval axis, which later enlarges as the reduction and absorption of the pro-entodermic mass proceeds. Finally, by such graduated method does the entoderm become established. At no time is there a mouth or other means of communication with the outside during phases of embryonic or larval history. Planulae of Hydractinia have been frequently reared under artificial conditions, and readily transform into the final, or polyp state. Soon after the larva attaches itself the mouth is established by a terminal opening which arises by a rupture and rearrangement of the adjacent cells. Tentacles arise in the usual manner, first three in number, followed shortly by three others at intermediate points, and slightly below the first series. At the base of the polyp there arise root-like stolons, two or more in number, which mark the origin of the hydrorhizal network characteristic of the species.

\section{Clava leptostyla Ag.}

In connection with the work on Hydractinia I have taken occasion to re-examine the material upon which was based the work embodied in my previous paper on Clava ('06), and have also carefully studied sections of new material which had been fixed in 
Bouin's picro-formol, and in Zenker's solution, and carefully stained by several of the most recent methods. So far as jt relates to the organization of the egg or its cleavage no occasion has been found for modifying in any essential the earlier conclusions. These I believe to be confirmed in every detail, and lead me to reaffirm the former account. Concerning some few points in relation to the phenomena of maturation and nuclear behavior, including phases of germ-layer formation not touched upon in the previous paper, it is necessary to reconsider and add to the former results.

1. Maturation. Concerning the phenomena associated with maturation my observations will be very brief. In the former paper the general facts were explicitly stated and no occasion has been found to call for essential modification. Both in living eggs and in sections of stained material polar bodies were found and described. In connection with earlier accounts of this feature in other eggs of hydroids one may find such expressions as "About this time the nucleus becomes indistinct and finally disappears;" the nucleus "fades from view when the ovum is deposited." These accounts relate almost wholly to observations upon living eggs, and I have repeatedly verified them both in the living, and in sections of fixed eggs. While in themselves such accounts may seem to have little of distinctive value, in a morphologic sense, yet, as expressive of physiological conditions they seem to me to have very large significance. In the first place, these observations described what was actually seen and its fidelity to fact can not be questioned. In the next place, cytological study of fixed material confirms just these accounts. As eggs grow toward maturity the germinal vesicle is large and conspicuous. But as they approach the phase of metabolism involved in maturation a marked change occurs, as is well known. The chromatin network, which has been conspicuous, gradually disappears, and in many cases loses absolutely its affinity for stains. With dissolution of the nuclear membrane, a still further change occurs, which is exactly what these accounts describe, namely, the mingling and fusion of nucleus and cytoplasm to such a degree that it is often difficult to differentiate them by any of the usual methods. 
It is just at this time that the maturation phenomena are in process of development. In my previous account some doubt was expressed as to the presence of mitosis. Critical study of fresh material has enabled me definitely to confirm the facts of maturation mitoses attested by Smallwood ('09) in Hydractinia, and Beckwith ('09), in Clava. A critical review of my earlier material only went to confirm the previous doubt; all of which but tends to resolve the case to one of technique. In the newer material both maturation mitoses were distinguishable without serious difficulty.

2. Nuclear behavior. In addition to the foregoing discussion some further reference to points of nuclear behavior seems desirable. In several of my earlier accounts attention was directed to the migration of the nucleus to the distal periphery of the egg as it approached maturity. As is well known, many earlier students of nuclear physiology have sought to correlate directly the nucleus with nutritive functions during the growth period, and its location has been said to conform to this conception, and numerous citations made to facts recorded in phyla above protozoa. So far as the Hydrozoa are concerned I am not able to confirm this view. In the growing oocyte of Clava the germinal vesicle is rarely if ever directly contiguous to the nutritive surface of the spadix, and in the period of later growth invariably migrates to the distal surface and comes to lie in immediate contact with the outer wall of the gonophore. While I have not made any attempt at this time to take up the problem for critical inquiry and investigation, yet my general observations tend to render extremely doubtful the view above suggested, at any rate in any very explicit and causal sense. That the nucleus may function in this matter in a general way as in many other vital functions may be probable, yet that its primary or fundamental and direct part in the oocyte has to do with nutritive more than other functions of cell life seems more than doubtful. It may easily be shown that processes of nutrition, along with other phases of metabolism, are functions of the entire cell working as a whole. In the earlier paper attention was directed to the phenomena of metabolism as related to the origin and development of the pig- 
ment granules of the egg, and it was pointed out that they appeared first in the region of the nucleus, and from this extended as a peripheral zone over the entire egg, the process continuing up to, and even beyond, the phenomena of maturation, which would seem clearly to imply that at most the nucleus was concerned only in the origin of this process, since it early became involved in other functions of very different character.

3. The chromatin. In addition to what has been said in this connection as relates to Pennaria and Hydractinia a few facts may be mentioned as directly bearing on the matter of nuclear fragmentation. In figs. 31 and 32 are shown phases of nuclear behavior associated with maturation. Fig. 31 is a careful drawing of a condition not at all unusual in these eggs. Here one finds undoubted evidences of chromatin fragmentation and dispersal prior to the dissolution of the nuclear membrane. As will be noted, there is as yet no definite disintegration of the nucleolus, which is quite intact, though with a large vacuole. Chromatin granules are variously distributed through the nuclear network, chiefly at nodal points as shown. But the same sort of granules are to be seen just outside the nucleus, and are indistinguishable from those shown in the next figure, in which the nucleus is in process of disintegration, the membrane being entirely dissolved, and the network also surely disappearing. Here also the nucleolus is about to collapse, being flattened on one side, as if ready to go to pieces. Numerous cases of this sort occur in these eggs and seem to confirm what has been said above, that a degree of fragmentation both of nucleus and chromatin is apparently a constant feature. In a few cases I have found these features actively associated with maturation, the first polar body having been already formed.

From this it will be noted that fragmentation of the nucleolus may not occur until that of the nucleus is well under way, as shown in the figures already cited.

I have called attention to the problem of nuclear fragmentation in several of my earlier papers, ('04a, '04b, '06,), and in a paper now in press on the development of Cyanea ('10), attention is directed to very similar conditions associated with maturation. 
It is not a new problem; many investigators having directed attention to the matter. Strangely, however, there has been no very serious attempt to explain its probable significance, further than to suggest, as Wilson had done long ago ('00), its possible relation to the extremely active metabolism involved during the growth period of the egg. Unfortunately, there seem to be serious difficulties involved in such an interpretation; for example, the fact that in many ova growth seems to be almost nil. Furthermore, it is not ceriain that just this type of fragmentation occurs in all eggs just at this period. But whatever may be its significance certain it is that in large numbers of organisms there seems to occur at this time this very interesting fact, that a largely preponderating proportion of chromatin is lost, or at least takes no part in the formation of the chromosomes, and so is a negative factor so far as relates to chromosome function or theory. The bearing of this on the question of chromosome individuality is not without great interest and importance; but no attempt can be made to discuss the problem here. It may be suggested, however, that defenders of the extreme views of chromosome individuality in its morphological sense,-and only in such sense has it any essential significance,--are confronted with a problem, the complexity of which is beyond estimate, and the difficulty of which is hardly less so. Let him who finds difficult the intricacies of 'germ-plasm' hypothesis beware in essaying to unravel the no less intricate mystery, or miracle, of preserving individuality in the metabolic maze through which chromatin must pass in every cytogenic cycle!

In the previous paper (op. cit.' 00, , p. 227), attention was directed to the very anomalous aspects of nuclei during early cleavage, features of which were shown in several sketches. Certain of these presented rather strong indications of amitosis, though the condition of the chromatin was such as greatly to obscure the finer details of nuclear structure, and the suggestion was made that "certain phases of the mitotic mechanism may be disguised or actually lacking." As shown above, mitosis has been demonstrated during maturation, yet something of the original doubt remains as to mitosis during early cleavage, the newer material 
affording no appreciable advantage over that used in the former instance. At this time the chromatin appears only in the form of extremely irregular, flocculent patches, scattered here and there through the cytoplasmic cell-like aggregates. The same elongated, clavicular, or dumb-bell shaped nuclei previously described are found in the newer material treated by latest methods. Under ordinary treatment the chromatin stains so intensely as seriously to obscure details of structure. Only by prolonged destaining and clearing, and by more delicate staining with picro-hematoxylin has it been possible to reduce somewhat the flocculent aspects. When this is done one may distinguish a granular chromatin constitution, but the chromosomes have defied all attempts to render them distinctive either in form or in number. This relates to conditions in early cleavage, as was pointed out in the previous paper, aspects of mitosis become fairly clear in later cleavage. Beckwith describes mitoses in early cleavage but makes no reference to the anomalous conditions here described.

With all the pains taken in preparation of my material it must be allowed that these conditions are not artifacts, but facts entitled to the same consideration as others of similar treatment. It must be admitted however, that, even at best, our latest refinements as to staining technique must be accepted as only tentatively trustworthy. In other words, it becomes more evident every day that in protoplasmic and nuclear metabolism there are such incessant and intricate variations of chemical conditions that one may not assert that a given stain or fixing agent affords any certain test of a given state at a given time. On the contrary, it will not be denied that a given stain may act in one manner on one cell and on another very differently; or indeed, that it may in another case fail utterly to yield any results whatsoever in differentiation. Under the aspects of chromatin organization, or perhaps better, lack of organization, as here portrayed, it has not been possible to obtain any definite information as to the number or character of the chromosomes. But it may be said, as before mentioned, that in Clava, as in Pennaria and Hydractinia, there is an enormous fragmentation and dispersal of chromatin at the time of maturation, most of which must be utterly 
lost as chromatin, unless some may be recovered during phases of cleavage, as suggested in the previous paper. Some further reference to this feature will be made in a later section of this paper, in connection with the discussion of theoretical problems involved in the general subject.

Incidentally it may be worthy of mention that in at least one case two germinal vesicles have been demonstrated in a given egg. So far as the writer is aware this is a rather rare occurrence, though probably not more so than that of hermaphrodite gonophores, as described in the previous paper (p. 211). Fig. 23 is a careful camera sketch of these nuclei. There was not the slightest evidence to show that there might have been a fusion of two oocytes in this case, as sometimes happens in other hydioids, the egg being only of average size.

4. Nucleolar behavior. In the previous paper (p. 221), attention was directed to some aspects of nucleolar changes associated with maturation. Among these that of vacuolation was particularly mentioned, as was also that of the migration of the nucleolus from the nucleus into the cytoplasm. The latter feature is rather unusual, and is not probably of any large significance. More important is the fragmentation which is a rather common feature. Prior to maturation the nucleolus exhibits various phases of vacuolation. In some cases several vacuoles of slightly differing sizes appear, some of which may later fuse into a larger vacuole. In other cases one finds a single large vacuole which finally occupies almost the whole of the nucleolus, at which time it may happen that the body collapses upon itself, or gradually goes to pieces, i.e., fragments In other cases there may be in a given nucleus two nucleoli, one highly vacuolated and evidently degenerating, the other having all the appearance of a new organ, without signs of vacuoles. ${ }^{1}$ These changes usually occur while the nucleus is

1 In this case the larger, vacuolated nucleus exhibited a most interesting phase of apparent fragmentation. Almost the whole organ comprised a single large vacuole, and adhering to the outer surface were numerous deeply staining spherical granules borne upon delicate pedicels, the whole resembling a sort of pin-cushion aspect. Just what significance such a condition may have in relation to nucleolar metamorphosis, or its bearing on the problem of chromosome formation, as 
yet intact; and in some cases, at any rate, the entire fragmentation, or dissolution of the nucleolus may occur before the nuclear membrane disappears. In other cases nucleolar dissolution and disappearance take place coincident with the nuclear dissolution and maturation, as stated in a preceding section. In some instances the nucleolar degeneration seems to involve a gradual process of shrinkage, probably by solution or absorption by the nucleoplasm. It has been no part of my present purpose to study the matter of nucleolar genesis, or the possible relation of nucleolar metabolism to the genesis and differentiation of chromosomes. An interesting and varied literature on this subject has grown up with recent times, some of which seems to have a profound significance in relation to chromosome theory. But to enter upon this phase would involve time and details far beyond the scope of the present paper.

5. Later development. It is not the purpose to enter into any considerable details as to later aspects of development save as they are found to be more or less exceptional as compared with other species concerned. As to cleavage no occasion has been found to modify the account already given in the former paper (pp. 223 to 227). There is much here in common with that known in Tubularia, Hydractinia and Pennaria. While in a certain proportion of the eggs cleavage is more or less regular; on the other hand, in a large proportion, irregularity and lack of order or symmetry is the rule. This is particularly the case with those ova which are flattened laterally against the sides of the spadix of the gonophore. In the case of ova terminally placed in the gonophore the shape is more nearly spherical, and in such cases the tendency is toward regularity. This is what one might naturally expect; yet there are notable exceptions, and one will do well to remember the extremely erratic cleavage of such ova

suggested in a following sentence, I am not prepared to suggest. The nucleus of this egg was in rather typical resting condition, and its chromatin of the usual granular spireme aspect. As stated in another connection, different modes of fixation and staining have appreciably different effects on the egg cytoplasm and nucleoplasm, so that much more elaborate observations would be necessary ere one might venture any very positive opinions on so complex a problem. 
as those of Pennaria, Hydractinia and Turritopsis, where the freedom of the egg from all influence of gonophore walls, etc., ought to afford perfect conditions as to regularity of cleavage. It may not be improbable that external conditions of pressure, etc., have an appreciable influence on cleavage, but such facts as those just cited clearly indicate that there are other factors concerned which are probably more potent than the merely physical ones of pressure, gravity, etc.

6. The morula. As in Hydractinia and Pennaria, the early embryo in Clava is a morula. Cleavage results in a solid mass of cells, with only incidentally a sign here and there of an intercellular space, and in only rare instances anything comparable with a segmentation cavity. Indeed, one might venture to aver that such cavity is conspicuously absent throughout the ontogeny of this hydroid. As already pointed out, this is not peculiar, but rather the general fact in hydroid development. Something further will be said on this point in a later connection. There is nothing in the morula stage in Clava which differs appreciably from that of the other species already referred to. As the embryo reaches the morula condition it assumes the usual spherical shape, whatever may have been the shape of the egg during cleavage or growth. Evidently the walls of the gonophore do not afford any very serious barrier to this change, for one finds all conditions of shape from the flattened lateral pocket of the growing oocyte to the spherical terminal capsule, and the oval capsule of the planula, all derivable in turn from the first as the embryo grows and finally emerges as a pear-shaped planula.

7. The germ layers. What has been said on this subject in connection with Hydractinia may be affirmed of Clava. Granted the assumption of a morula as the primitive embryo, and there is no occasion for question or discussion concerning the segmentation cavity, delamination, multipolar immigration, etc. Absolutely nothing of these is involved in the case under consideration. At the time of the completion of cleavage,-indeed before this, when the morular aspect first begins to take shape,--we have only a spherical cell mass, with syncytial tendencies, and as yet without sign of tissue differentiation. In fig. 29 is shown such 
an early morula-like embryo. In this is shown an oval embryo without definitive ectoderm, or sign of entoderm. This condition persists for some time, the only changes distinguishable being that of cell proliferation, or perhaps more precisely, nuclear proliferation; for in most cases it is not possible to distinguish the presence of cell boundaries of any definitive sort. But a most remarkable thing becomes apparent under careful staining, -namely, the fact that the internal mass shows a differential staining reaction, represented by the shaded interior. This I take to be indicative of an important physiological change, namely, an incipient entodermal differentiation directly related to the primary purpose of entoderm development, that of digestion. While the results do not as yet warrant a dogmatic pronouncement on this matter, they do tend to confirm a view I have already proposed (cf. Science, March 25, 1910). It has generally been assumed that the ectoderm is the primary germ layer, and morphologically this is undoubtedly true. But if the suggestion just made be confirmed by later experiments one will have to aver that, physiologically speaking, the entodermal function is the first to express itself. Further consideration of this point will be deferred to a later section.

a. Ectoderm. The development of this tissue is a graduated process. With the establishment of a surface layer of cells of more or less similar character one is not warranted in designating it as a definitive ectoderm. For, as Rittenhouse has pointed out ('07, p. 453):

Even those cells which are at the surface at the completion of segmentation cannot be regarded as primitive ectoderm, for in the breaking down of the cell boundaries, the formation of the syncytium, and the recasting of the cells, it is quite impossible to say what changes of protoplasm may take place.

Furthermore, it must not be overlooked that, with a primary layer of cells established, there are yet other ectodermal elements to be taken into account, such as interstitial cells, cilia, nettling cells, etc. Only with the formation of the supporting lamella can it be claimed that the definitive ectoderm is really established. 
b. Entoderm. As in the case of the ectoderm, what has been said as to entoderm formation in Hydractinia will apply for the most part to Clava. What has been said above in reference to the morula as the primordial embryo applies in this connection. Entoderm formation is a graduated process, and in its morphology a much slower process than that of the ectoderm. In its physiological genesis it may be said to outrun the ectoderm; for its functions begin almost immediately after the completion of cleavage. As was pointed out in an earlier section, the internal cell-mass included within the primordial ectoderm is not in any sense a tissue, but rather a primordium,-pro-entoderm. For some time following the nuclear proliferation of this mass continues. But at the same time another, and extremely different process is under way, namely, that of cellular and nuclear disintegration and destruction. Out of this interior mass relatively few cells will survive to constitute the definitive entoderm of the polyp. What is taking place is in reality a struggle among these cells for nutrition, reminding one of the ingenious theory of Roux ('81), 'Der Kampf der Theile im Organismus,' though, so far as I am aware, this author never applied his theory in this direction. It is not until after the planula has become free that a definitive entoderm is finally established; indeed, this does not become established until near the metamorphosis of the planula into a polyp, though one may trace stages in the process much earlier. What really happens is that the same sort of vicarious process of nutrition occurs as that by which, in many hydroids, the oocyte grows; that is, the devouring of sister cells or primordial ova; in the later stage occurs the similar process of digesting the pro-entoderm cells and making their substance available as nutrition to the embryo. As is well known, these pro-entoderm cells are richly laden with yolk granules, as were also originally the cells of the ectoderm. But long after the ectoderm has exhausted this primitive supply the entoderm is reducing its surplus cell mass for similar ends.

With the gradual advance of this process the coelenteron of the larva grows larger, appearing in sections as an axial slit of irregular outline, and later assuming a more regular aspect and 
becoming more capacious. As the entoderm cells become definitely organized and adjusted in contact with the supporting lamella the entoderm may be said to be established as a tissue. But this does not become complete until a large proportion of the proentoderm mass has been reduced and appropriated by the embryo. There yet remains masses of cells in the cavity along with yolk fragments and other debris variously distributed.

Earlier accounts of the differentiation of the entoderm differ in several particulars from that here given. In the first place, it has been generally assumed that the entoderm is early established, an error which I have taken occasion in several accounts to correct. In the next place, the exact mode of its differentiation has not been very critically studied, nor the fate of those parts of the pro-entoderm not directly concerned in entoderm formation. For example, Korschelt and Heider, following the older accounts, have asserted that following the establishment of the entoderm the remaining cell-mass undergoes fatty degeneration, serving in part as food matter, with a residual mass of debris, the fate of which is not formally stated. I have not found in my preparations any evidence of such fatty degeneration, though, as stated above, I have found direct evidence of the operation of digestive ferments. According to Wilson ('83) something akin to amoeboid engulfment of these cells and their intracellular digestion is tentatively suggested:

These appearances suggest, though they do not prove, that the yolk granules and spheroids pass bodily into the cells. I have never seen them in the act of passing into the cells, but the technical difficulties are great, and the other considerations seem sufficient weight to warrant the provisional acceptance of the view advanced.

That something of such amoeboid engulfment may occur is not altogether improbable; though I have found slight evidence of it. We know that in the growth of the oocyte in certain species just such a process does take place, and its occurrence in the slightly later history of the embryo would be what might naturally be expected. Indeed, I have, in an earlier part of this paper, suggested such a process in the behavior of the cells of the pro- 
entoderm during differentiation. But associated with the process there are strong evidences of the action of digestive ferments which are set free by these cells in which this process is first set up and carried forward. This likewise takes place in the case of the oocyte during growth, as has been shown by many recent observers. The suggestion of Metschnikoff long ago, that intracellular digestion forms the dominant, if not the only digestive process in coelenterates, is not borne out by recent investigations. For example, it is well known that medusae, actinians, etc., capture highly organized prey, such as crustacea, fish, etc., and digest it quite after the fashion of the higher Metazoa. The same thing is easily demonstrated in hydroids, in which small organisms, like worms, copepods, etc., form an important food supply. Gland cells are well known in the entoderm of Hydrozoa and are evidently associated with digestive functions. Hence it seems more than probable that enzyme digestion is no less a feature in this than in other animal groups; and that it more than any other, is the mode involved in the reduction of this inner cell mass of the planula is almost certain. This in no wise contravenes the fact of the presence of yolk granules in the entoderm cells, for they were original constituents of these cells, just as in the case of the primordial ectoderm cells. Whether such yolk granules are ever taken in entire by the larval entoderm may be open to doubt, at least till better sustained by direct evidence than at present.

So far as I am aware, the general conception herein outlined as to the physiological processes involved in this phase of larval development has not been hitherto proposed. Of its fundamental validity there seems no serious objection and much direct evidence. In brief, it involves these facts: First, that of the pro-entoderm mass of cells relatively few go to constitute the definitive entoderm of the planula. In the second place, the primary process involved in the necessary differentiation must be one of selection. So far as one can distinguish these pro-entoderm cells are alike in form and potency. The primary demand in embryogeny is growth, which involves nutritive material in some form. And the only source of such is that associated with these cells 
as yolk granules, which can only become available by the dissolution of the cells which contain them. Supposing that originally it was equally distributed, it could only remain so by the further assumption that cell division was likewise equal and continuous throughout. This we know is seldom the case, being in general inversely as the amount of yolk varies. Hence those cells whose growth and metabolism became more rapid would first exhaust their own deutoplasm and demand supplies from outside. And here must originate the struggle among cells which has been emphasized above.

Assuming the substantial truth of the conception we must face the implication that the older views as to the ontogenic and phylogenic significance of the germ layers are discredited by these further facts, as they have also been in theory. I believe we may, therefore, conclude that fundamentally the phenomena involved in germ-layer formation are primarily physiological processes, and relate to protective, motor, and nutritive ends; and that only secondarily, if at all, can they be supposed to have any significance in ontogeny or phylogeny.

\section{REVIEW AND DISCUSSION}

As stated in an early section of this paper one of the purposes in view was to review certain phases of current and earlier theory and doctrine concerning problems of ontogeny, in the light of recent knowledge, and to seek to point out and correct such errors as may easily come within the scope of pertinent discussion. This seems to the writer particularly important and desirable just at this time of virile criticism and readjustment.

For some time the conviction has grown that not a few of the earlier views and theories touching ontogenetic problems had outlived their days of service, and that new facts were demanding new methods of interpretation. For example, who today pretends to invoke, in its original content, the Recapitulation Theory in correlating ontogeny and phylogeny? Who would seriously defend, or use the so-called laws of cleavage in interpreting every phase of egg development? And so one might multiply examples. 
The fact remains, however, that just these outgrown systems or theories still cumber the literature, the available text-books and manuals for introducing students to these subjects of present day biology, much to the reproach of its leaders and sponsors.

With the desire to aid, in however small a degree, in correcting phases of error, or what appear such, the writer will aim under this section of the paper briefly to pass in review the chief aspects of the problems involved, and, so far as may be practicable, will endeavor to show distinctive examples of inadequate theory and erroneous implications and deductions.

\section{Origin, multiplication, and growth of germ-cells}

It seems worth while briefly to summarize results which observations, more particularly my own, have brought to light on these several aspects of ontogeny. Many of the facts have already been made known in previous papers, but care will be taken to avoid, as far as may be, any unnecessary duplication, giving attention chiefly to those features relating to phases which seem to call for consideration. Concerning the earlier controversy as to the mere place or tissue in which the germ-cells arise, it is no longer necessary to multiply words. Recent work from various sources, and especially that of Goette ('07), has, I believe, placed the subject beyond further dispute. That there is any such region as may be designated a 'Keimzone' or 'Keimstätte' may be at once dismissed as absolutely without warrant as a general proposition. Furthermore, that the germ cells have their origin in the ectoderm alone in hydromedusae may be similarly denied and dismissed as unworthy of further inquiry or doubt. And still further, I am thoroughly convinced that the still more recent controversy as to the hypothesis of the 'germ-plasm,' if not as clearly a delusion as the preceding, is yet without the slightest support from the ontogeny of the group under review.

It is a matter of easy demonstration that in many species of hydroids the egg may be followed in every detail from its origin as an ectoderm or an entoderm or interstitial cell through its gradual differentiation and growth to maturation, as a distinct individual 
cell, without the slightest tendency to multiplication. That is to say, in species of Eudendrium, Hydractinia, Campanularia, Pachycordyle, and others, there is at no time any organ which is ovarian in character, within which masses of primordial ova arise and pass through oogonial and oocytic phases familiar in other species to be mentioned later; but a given cell of the entoderm which is to give rise to an egg begins to grow, and either in situ or after migration into the gonophore, develops directly into a typical egg, and later, after fertilization, gives rise directly to an embryo and finally to an individual polyp. On the other hand, in many cases, e.g., Pennaria, Tubularia, Syncoryne, Hydra, large numbers of primordial ova arise in what may be regarded as an ovary where, by a series of cytological changes, they exhibit the oogonial and oocytic phases referred to above. These somewhat strikingly different modes of oogenesis may, for convenience be designated as the 'direct' or 'individualized' and the 'indirect' or 'oogonial' modes. That they are sharply distinct, or qualitatively differentiated types of oogenesis is not claimed. In this, as in other phases of development, there are all shades of intergradation and relation to be found in these and other species of Cnidaria.

Correlated with these apparently widely divergent modes of origin are those of nutrition and growth. In the 'direct' or 'individual' ova nutrition is almost invariably likewise through. the direct medium of the adjacent tissue cells, which supply by diffusion the appropriate nutritive plasma. On the other hand, in ovarian eggs, which involve oogonial and oocytic generations, there arise indefinite masses of primordial ova; and the growth of certain of these as ovarian eggs, is largely through the active appropriation of the excess primordial ova, which are literally devoured whole, or predigested to a liquid plasma, which is then absorbed. Illustrations of both these processes are too familiar to call for special emphasis. While the two processes of nutrition are thus apparently different, intermediate cases are not unknown, e.g., Eudendrium hargitti, recently described by Congdon ('06, p. 39) has been found to comprise something of both modes. And, though it belongs to a genus in which oogenesis 
is associated in its nutritive relations with the direct activities of the tissue cells of the parent organism, yet in this particular species the egg certainly turns parasite, if not cannibal, and devours bodily the cells of either ectoderm or entoderm as may happen to afford it particular support at a given time. And one finds in these growing ova of E. hargitti eggs literally loaded during most active growth with the engorged nuclei of tissue cells, the exact counterpart of those conditions found in Pennaria and Tubularia in which the growing eggs are similarly packed with the primordial ova of the ovarian tissues.

In his earlier studies on heredity Weismann admits that germcells may be derived from somatic cells, e.g., (Essays on Heredity 1, p. 209):

It is quite impossible to maintain that the germ-cells of Hydroids or of the higher plants exist from the time of embryonic development, as indifferent cells, which cannot be distinguished from others, and which are only differentiated at a later period. Such a view is contradicted by the simplest mathematical consideration; for it is obvious that none of the relatively few cells of the embryo can be excluded from the enormous increase by division, which must take place in order to produce the large number of daughter individuals which form a colony of polyps. It is, therefore, clear that all the cells of the embryo must for a long time act as somatic cells, and none of them can be reserved as germ-cells and nothing else; this conclusion is moreover confirmed by direct observation.

In later discussing this feature, while still contending that in most cases germ-cells arise early in ontogeny, Weismann is yet compelled to admit that in Hydrozoa these do not arise till very late, and indeed in individuals of a later generation, (Evolution Theory, vol. 1, p. 410). Notwithstanding this admission he still contends for his dogma of germinal continuity:

Here the primordial germ cell is separated from the ovum by a long series of cell-generations, and the sole possibility of explaining the presence of germ-plasm in this primordial cell is to be found in the assumption that in the divisions of the ovum the whole of the germ plasm originally contained in it was not broken up into determinant groups, but that a part, perhaps the greater part, was handed on in a latent state from cell to cell, till sooner or later it reached a cell which it stamped as a primordial germ-cell. Theoretically it makes no difference whether these germ-tracks, that is, the cell generations which lead from the ovum to 
the primordial germ-cells, are short or very long, whether they consist of three or six or sixteen cells, or of hundreds and thousands of cells. That all the cells of the germ-tracks do not take on the character of germ-cells must, in accordance with our conception of the maturing of determinants, be referred to the internal conditions of the cells and of the germ-plasm, perhaps in part also to an associated quantum of somatic idioplasm which is only overpowered in the course of the cell divisions. This splitting up of the substance of the ovum into a somatic half, which directs the development of the individual, and a propagative half, which reaches the germ-cells and there remains inactive, and later gives rise to the succeeding generation, constitutes the theory of the continuity of the germ-plasm (p. 411).

Theoretically, the hypothesis is interesting and developed with much plausible argument. Yet its demonstration is far from evident, indeed quite beyond demonstration, as has been frequently pointed out by many of his critics. However, Weismann insists that there are evidential facts:

The hypothesis does not depend for support merely on a recognition of its theoretical necessity, on the contrary there is a whole series of facts which may be adduced as strongly in its favor. Thus, even the familiar fact that excision of the reproductive organs in all animals produces sterility proves that no other cells of the body are able to give rise to germ-cells; germ-plasm cannot be produced de novo.

It is passing strange that he should ignore the body of facts concerned in regeneration, and among them the reproductive organs. And it is still more strange that in support of this he should cite in detail the Hydrozoa as illustrating and supporting the hypothesis, ignoring the well-known facts that among these are abounding evidences which afford insuperable objections to just these assumptions. The present author has, in many cases, shown that gonads may be as readily regenerated by hydroids and medusae as any other organs; and that not for once or twice, but repeatedly in the same specimen, and that de novo and in situ; not the slightest evidence being distinguishable that any migration through pre-existing 'germ-tracks' occurred. The assumption that in these animals the gonads have "been shifted backwards in the course of phylogenetic evolution, that is, have been moved nearer to the starting point of development" seems so at variance with known facts as to be difficult to appreciate 
or respect. That "the adherence of the sexual gonophore to the hydroid colony has made a more rapid ripening of the germ-cells possible," or that "nature has taken advantage of this possibility in all cases," as claimed by Weismann, is but another example of subservience to theory; for I cannot believe he can be ignorant of the general fact that there is not the slightest evidence that in hydroids with fixed gonophores the germ-cells ripen more rapidly or more frequently.

It is in vain to attempt to bolster up these speculations by cleverly designed diagrams; for such devices are too often mere products of a vivid imagination. Furthermore, it is difficult to account for the dogmatic persistence with which this writer seeks to sustain the view that the germ-cells originate exclusively in the ectoderm. In the earlier work, which makes up his splendid monograph already referred to, he has admitted again and again the probable origin of the cells in the entoderm (pp. 215-217). But in his 'Evolution theory' (p. 415), it is asserted, "in no single case is the birthplace of the germ-cells to be found in the entoderm, but always in the ectoderm, no matter how far back it may have been shunted." And in citing cases in support of the point he refers to Hydractinia and Podocoryne, both of which are known to prove the exact opposite, as shown by Bunting ('94) and Smallwood ('09), as well as by the writer in numerous similar cases.

The following critique by Lloyd Morgan ('91) is pertinent in this connection:

This germ-plasm resides in the nucleus of the cell; and it would seem that by a little skillful manipulation it can be made to account for anything that has ever been observed or is likely to be observed. It is one of those convenient invisibles that will do anything you desire. The regrowth of a limb shows that the cells contained some of the original germ-plasm. A little sampled fragment of Hydra has it in abundance. It lurks in the body-wall of the building polyp. It is ever ready at call . . . . Now, although I value highly Professor Weismann's luminous researches, and read with interest his ingenious speculations, I cannot but regard his doctrine of the germ-plasm as a distinctly retrograde step. His germ-plasm is an unknowable, invisible, hypothetical entity. Material though it be, it is of no more practical value than a mythical germinal principle. By a little skillful manipulation, 
it may be made to account for anything and everything. The fundamental assumption that whereas germ-plasm can give rise to body-plasm to any extent, body-plasm can under no circumstances give rise to germplasm, introduces an unnecessary mystery . . . . The fiction of two protoplasms, distinct and yet commingled, is in my opinion, little calculated to advance our knowledge of organic processes.

It has been assumed, as the foregoing citations clearly show, that there is some predetermined order of sequence and relation as to the origin, nutrition, growth, etc., of germ-cells, not only in such a group as the hydrozoa, but throughout the animal kingdom. And with this as a postulate assiduous search has been directed to its support. It is not necessary that one should, a priori discredit the method, for it is perfectly scientific,一within limits. The fault which must be emphasized is that it has been so conspicuously partial and dogmatic. Facts quite as accessible, quite as convincing, have been silently ignored; and it is thus that such work or method becomes both unscientific and untrue. I believe the foregoing facts must suffice to show that, both as to origin, differentiation and growth, the germ-cells of the Hydrozoa, so far from sustaining the doctrine of the germ-plasm, afford the strongest and most direct evidence to the contrary.

\section{Doctrines of homology}

If one were asked to indicate the dominant conception which characterized the biological activity of the greater part of the nineteenth century he could hardly go far amiss in phrasing it somewhat as follows: The perennial and irrepressible search for homologies! This would be confessedly the case with so much of the period as comprised the Darwinian epoch of biology. But the conception belongs quite as properly to the seething period of the biological renaissance of the early half of the century, and finds expression in the researches of von Baer and Cuvier, Lamarek and St. Hilaire, and a long roll of hardly less distinguished names. But strangely enough the doctrine had antipodal significance under the early, as contrasted with the later epochs of thought. To the first homology embodied the postulate of types of creation according to the conception of 'archetypes' of plan and 
structure, details of which have been elaborately developed by Owen ('48) whose well-known 'Homologies of the vertebrate skeleton' is its best expression. But to these naturalists homology meant likeness of structure merely, with the implications of ideals and design. To naturalists of the later period the conception took on an infinitely larger scope and significance. Like the former, they were free to accept likeness of structure as an index of homology; but following the blazed trail of Lamarck and St. Hilaire, they conceived in the doctrine the key to lineage. To them homology involved kinship; and 'archetypes' as such had no vital meaning. It is not strange that, under the masterful hand of Darwin, the newer doctrine gave to biologists a working hypothesis comparable with that of gravitation, and at once placed biology on the foundation of scientific certitude.

To naturalists of both periods must be ascribed well deserved praise. Both sought in the most conscientious and critical manner to discern the facts of homology. Among both were those of divergent and conflicting views, von Baer and Cuvier versus Lamarck and Hilaire; Agassiz versus Darwin. In both were elements of important truth; in both were extremes of mischievous error. It is not the purpose to undertake any critical review of the phases of conflict involved in these antithetic aspects of one of the most profound of biological doctrines; but rather, ignoring extremes of the earlier period, whose errors have largely gone into oblivion, to point out in briefest way wherein, under the ardent impulse of the newer view, something of extravagant over-valuation has come to have a retarding and mischievous influence upon biological thought and progress. It hardly need be said that in this matter attention will be directed to those points in particular which have come under my own lines of research. A similar duty has been ably performed upon a larger scale by several brilliant authorities, among them Wilson ('94), Morgan ('03), Montgomery ('06).

a. The germ-layers. No occasion exists for a review of the origin of the conception of germ layers developed through the work of Wolff, Pander, von Baer, Remak and Kölliker. It is sufficient to my purpose to cite the astute observation of Huxley 
as to the likeness of the diblastic tissues of coelenterates and the mucous and serous layers of the embryo ('49). Let it be noted, however, that Huxley does not designate these as homologous, but rather as analogous. Ten years after his first utterance he remarks "It by no means justifies the assumption that the Hydrozoa are in any sense arrested developments of higher organisms. All that can be justly affirmed is, that the Hydrozoon travels for a certain distance along the same great highway of development as the higher animals." (Oceanic Hydrozoa, p. 2.)

Interestingly enough, the embryological researches of the time, led by Kowalevsky, Gegenbaur, Haeckel and others, centered about this pregnant conception of Huxley and led Haeckel to formulate his famous Gastraea Theory, with all its far-reaching implications as to the homology of the germ layers of all embryos, "from the lowest sponge to man." Of course, the gastrula at once sprang into a position of commanding importance in embryology, and as the prototype of Haeckel's hypothetical gastraea became a focal factor in embryological thought for a whole generation. It is not strange, therefore, that the Coelenterata, as the distinctively diploblastic phylum of the animal world, should early come in for a more than usual measure of interest and concern; and as the theoretical ancestral phylum from which all higher metazoa must have arisen, should have at once assumed a unique and dominant phylogenetic importance. When, however, it is clearly known that in only a single class of coelenterates does gastrulation occur, and that in no case is the gastrula, as an embryo, known, it seems remarkable to the point of surprise that the theoretical postulate should still be cherished by not a few students of phylogeny. Current literature, however, furnishes abundant evidence of just such adherence to tradition.

b. The planula. As is well known the planula is the distinctive larva of the entire phylum, including also the sponges. It has generally been assumed that the planula is a specialized gastrula, and that in some early species its enteron must have been formed by gastrulation. In this again there is involved the further inference and implication of the dominance of the biogenetic 
law. Granted the diploblastic character of coelenterate and sponge; granted further, the gastrula stage in ontogeny throughout a large proportion of higher Metazoa, who could well resist the conclusion jumped at by Haeckel as to the necessary homology of gastrula and planula, facts to the contrary notwithstanding!

c. The morula. It has just been stated that the planula is the distinctive larva of coelenterates. Another ontogenetic stage, however, must not be overlooked, namely, the morula. Of this one hears little now-a-days, though formerly it was a name fairly common in the literature of embryology. Even so recent a text-book as that of Korschelt and Heider devotes to it a single brief paragraph or so. They remark, "we shall see that examples of such a mode of origin of the two primary germ-layers are still ascribed to many Hydroids and Anthozoa, though probably the greater part of the cases referred to this method can be reduced to epibolic gastrulation, in which events the morula stage, as being a schema founded on erroneous assumptions, would have to be omitted." As an illustration of subserviency to dominant theory this sentence is a brilliant example! As a matter of fact epibolic gastrulation is absolutely unknown in coelenterate development, cases given of its occurrence having, without exception been proven egregious errors.

It might be questioned whether the morula, as a stage, should be given recognition. But when it is taken as the counterpart of the blastula, a stage everywhere recognized, but comparatively rare in the phylum under review, the objection vanished. The morula is far and away the dominant cleavage embryo in Hydrozoa and common in other classes, the Scyphozoa alone excepted. Accounts of its structure and origin given in an earlier section obviate any call for details here. Suffice it to say, that the complicated methods described by Metschnikoff ('86, p. 70), while interesting and ingenious, are but of small value. That delamination and immigration (polar or multipolar), may occur need not be questioned; but that they occur in any such degree of frequency or constancy as to constitute laws of entoderm formation none who has had to do with the problem would hesitate to deny.

While less importance is attached to this problem of germ layers 
than formerly, one still finds it more or less dominant in embryology. In his book, 'The Development of the Frog,' Morgan ('97) gives the subject usual attention; and in the still more recent book, 'The Development of the Chick,' Lillie ('08) devotes several pages to the subject, and it crops out repeatedly in the earlier chapters. The germ layer theory came to have a larger place than might otherwise have been the case in the attempt to discover some ultimate embryological basis for homology, and similar warrant for the so-called Biogenetic Law, or Doctrine of Recapitulation.

It has long passed as a cardinal doctrine in embryology that the primary germ layers form a constant, and more or less infallible basis for homology,-a sort of court of last appeal where other criteria fail. But not a few recent result's have tended to force the concession that even here there have been hasty generalizations. Not only in modes of formation and development have the germ-layers been found to differ widely, but in their function and fate in ontogeny there has likewise been obvious variation and discrepancy at many points. Balfour long ago called attention to discrepant modes of mesoderm formation, and recent experimental results have shown that organs of usual ectodermic origin are far from dependent on such mode of derivation. In coelenterate ontogeny the most radical divergences as to modes of origin are too well known to call for extended review. From the extreme mode of delamination exclusively in entoderm formation as pointed out by Metschnikoff in Geryonia, and since confirmed in substance by Brooks ('86), who calls it "very peculiar, and without any exact parallel," to that of gastrulation in Scyphozioa, with its confusing variations and exceptions, which involved those rancorous discussions of Claus, Goette, and others, and the more usual mode through the morula, the entire gamut of germ-layer formation might seem to be epitomized. But despite the misguided and essentially mischievous (however well meant), efforts to derive all these phàses from a mythical gastraea, now long a discredited and discarded phylogenetic monstrosity, the fact remains that there is probably no genetic relation whatsoever between them. 
d. The blastocoel. As another phase of the germ-layer problem, the cleavage-cavity calls for some passing notice. Formerly it had large attention at the hands of embryologists, and, though less emphasized at present, it has not passed out of consideration. One can hardly consult a current paper dealing with early development without meeting the problem of the origin of the cleavage cavity and its later fate in ontogeny. It is not necessary that one should assume to discredit entirely any possible morphogenic significance to this cavity in any group of organisms; but one does not need to study any considerable series of ontogenies to have forced upon him the conviction that its importance has been greatly exaggerated and correspondingly misinterpreted. One of the first impressions to be gathered from any considerable comparison of coelenterate embryology is that of the conspicuous absence of any definite blastocoel. It is only necessary to cite such figures as those given on plates I to III, illustrating these phases in Pennaria, Tubularia, Clava, Hydractinia to make this point very evident. It is true that here and there at certain stages of cleavage may be found irregular intercellular spaces which have been designated in general as segmentation cavities by those describing them. Spaces they undoubtedly are; but they are not cavities which have any permanence, either of form or position, but shift, or disappear under the erratic adjustments of the blastomeres; and one might about as well speak of the morphologic significance of the interstices in a box of oranges or bag of potatoes as of these promiscuous intercellular spaces.

Another feature may also be mentioned in this connection. That is the rather significant fact that in many species, such as Hydractinia, where during very early cleavage a cavity may appear incidentally, it almost immediately disappears, becoming totally and permanently obliterated by encroaching cells. And even in certain species, where a more or less characteristic cavity arises and persists for a time, as in certain Geryonids, I am constrained to interpret it as having a physiological rather than morphological significance,-a sort of embryonic receptacle for the deposition of cytolymph, or other substances developed during cleavage, or possibly for food matters derived from the water 
during early cleavage, or even later the retention of infusoria, as claimed by Merejkowsky ('83), though this may be doubtful.'2

Hence the facts herein adduced, together with the further fact of its extreme variation as to size, shape, position, or, still more significantly, its absolute absence in a large proportion of the species of the entire phylum, afford ample warrant for the conclusion that, so far from having any necessary morphogenic or ontogenic significance, the blastocoel may be said to be absolutely devoid of anything of the sort, least of all of any relation to phylogeny.

e. Cleavage homology. With the later development of the doctrine of homology there came to be involved varying phases of embryology, as shown above. One of its latest aspects is that concerned with cleavage, which has assumed a place of commanding influence within recent years, as expressed in the flood of literature which sprang into existence dealing with the subject from every point of view,-normal, artificial, experimental. Conklin ('97), has stated well the subject as follows:

In the whole history of the germ-layer theories I see an attempt to trace homologies back to their earliest beginnings. This problem is as important today as it ever was, and whether one find these earliest homologies in layers or regions of blastomeres or the unsegmented ovum itself, the quest is essentially the same. Within this question of the earliest homologies is included another of great and present interest, viz., the significance of cleavage.

With the broader implications and relations of this subject there is neither the time nor occasion for extended review in

${ }^{2}$ I can but express the strong conviction that those who contend for the presence in such cases of a definitive segmentation cavity and blastula are in serious error. It seems not at all adequate to aver that the absence of any true blastocoel is due to the 'abbreviation of this stage of development,' as G. T. Hargitt ('09) has designated it. As suggested above, but for the earlier theoretical significance involved in the matter, it may be doubtful whether any such contention would be made as that under review. To the writer it seems a pity to waste words over the subject in the form of argumentation. The facts are their own best exponent, and with these clearly apprehended there ought to be small occasion for controversy. The presence or absence of syncytial conditions has nothing whatever to do with the problem. Long before a syncytium has developed the morula has arisen as shown above, a fact as incompatible with the blastula as the planula is independent of the gastrula. 
this connection. With certain limited aspects of the problem as they relate to coelenterate ontogeny facts have come to knowledge which demand consideration. In a general way it may be said of the problem of cleavage homology that two rather divergent schools of biologic thought have grown up. One of these, ably represented by Driesch and $\mathrm{O}$. Hertwig, maintain that cleavage is a more or less general and quantitive process, the resulting blastomeres being largely equipotent in later development, their individual values depending largely upon relations of position, etc. The other wing of thought would hold that cleavage is fundamentally a qualitative process, involving a nicely predetermined and 'orderly sifting of materials,' resulting in a splendid 'mosaic work,' each cell fitted into its predetermined place with mathematical precision. Under the latter conception 'cell lineage' became the dominant problem of embryological research.

As a corollary to this, not only were blastomeres factors of supreme concern, but the natural and almost necessary implication followed that there must of necessity be predetermining factors in the unsegmented egg even more fundamental than those in the blastomeres. Hence came into prominence the search for evidences of 'formative stuffs', 'prelocalized germinal areas', etc. Waiving all further consideration of this particular aspect of the problem in its theoretical implications, I may very briefly cite facts concerned with coelenterate cytology, and attempt to show their bearing in the case.

In earlier contributions on the subject of cleavage, particularly in Pennaria and Clava, and further facts given in previous parts of the present paper, attention has been directed to facts which must be their own exponents. As to any blastomere homology in any of these cases it is difficult to conceive. Furthermore, both under normal conditions and through experiment, it has been demonstrated over and over that one or many blastomeres may be detached without in the least modifying the course of development in any particular. With such pictures as those in figures 1 to 30 before one, he would need be possessed of a measure of imagination peyond compare who could discern any sign of a 
'mosaic work'! And what shall be said as to the existence of prelocalized germinal areas in such ova? I have searched throughout the phylum for ova having any semblance of such, but without evidence of its existence. It was thought for a time that Clava might be a case, but the most painstaking efforts to detect it were only negative. For a time Conklin believed he had found such in the ova of Linerges, and so pronounced; but his final utterance ('08, p. 166), recalls this: "The view expressed in my preliminary note on the development of Linerges, that the three layers of the egg give rise to the ectoderm, the entoderm, and the mesogloea is not confirmed by further study."

That there may be certain special distribution of egg material I have already shown in the case of several hydromedusae, but this is by no means implies that it is germinal in character or definitely prelocalized.

\section{Amitosis}

In several earlier papers I found occasion to call attention to what seemed to be amitosis in cells during early cleavage. In several of these the evidence seemed direct and positive; in others the indications were somewhat general and indirect. The fact that several later students of cleavage in eggs of hydroids failed to confirm my results, while in the case of several others there has been very explicit confirmation, leads me to briefly review the matter as it appears at the present time. As I have elsewhere stated, the question of amitosis is purely one of fact. Whatever may be the implications of amitosis in its theoretical bearings on problems of heredity or otherwise, it must be evident that to attempt to discredit it on such grounds, or others of like nature, can only result in confusion worse confounded. One fact is just as sacred as another, and just as much entitled to respect and consideration, and is bound sooner or later to be taken account of. The extreme attitude of Ziegler, Vom Rath, and certain other cytologists who would have us believe that amitosis is to be found only in senile or pathologic tissues, will have to be abandoned as altogether unwarranted. Cytologists no less capable and conscientious, in growing numbers, accept amitosis as a normal 
and not rare mode of cell division. The following recent utterance of one of the avowed conservatives will show how just is this claim: "Accepting the idioplasm hypothesis . . . what do we know of its transmission? We may answer with assurance that it is transmitted from cell to cell by division; and we may safely presume, I think, in most cases by mitosis, though the direct or amitotic process may play a larger rôle than was formerly supposed." (Wilson, '09.)

My first suggestion concerning the problem was made in connection with my early account of Pennaria ('00); and the same year, Allen, one of my graduate students, made a similar statement in connection with the development of Tubularia. In a paper on regeneration, my son, G. T. Hargitt ('03), described abundant amitoses in the regenerating hydranths of Tubularia, and suggested the probable relations of the process to rapid growth and metabolism. In several contributions Child has also described amitosis, and in one in particular ('07), gave a brief account of the process in a series of organisms from coelenterates to birds. In one of these he made bold to predict that "future investigations will probably show that amitosis is at least as important in the life of the cell as mitosis." How timely was this prediction may be inferred by an examination of several recent papers on the subject, particularly by Patterson ('08), on 'Amitosis in the pigeon's egg,' and Glaser ('08), 'A statistical study of mitosis and amitosis in the entoderm of Fasciolaria.' In both these studies it is interesting to find so striking a vindication of Child's forecast. Patterson finds that at certain stages amitosis is quite as common as mitosis; and suggests "it seems very probable that amitosis is the result of special physiological conditions, which create a stimulus to cell division, . . . . whatever factors are involved in bringing about the rapid growth of any region would seem to be concerned in causing amitosis." This affords an interesting agreement with the suggestion made by G. T. Hargitt, as quoted above. Glaser also concludes "that amitosis plays in this instance "(Fasciolaria) "an important, if not the chief part in the differentiation of a definitive tissue." 
These several series of facts afford, as I believe, very strong confirmation of my own results as related to Eudendrium, Pennaria and Clava. They are also further supported by interesting results described by Young ('08) in connection with the 'Histogenesis of Cysticercus pisiformis.' In this paper is found the somewhat radical suggestion that cells may arise de novo, from a 'cytoblastema,' much as held by Schwann long ago.

It is not necessary to review this phase further than to point out its relation to a similar suggestion made by the writer concerning a somewhat similar origin of cells after nuclear fragmentation in both Eudendrium and Clava. Several of Young's figures are strikingly similar to those given in connection with Eudendrium.

Another most interesting confirmation of my results is to be found in the account of Brooks and Rittenhouse ('07), of the development of Turritopsis. In this case both mitosis and amitosis are found occurring 'simultaneously in the different cells of the segmenting egg.' The varying size of the amitotic nuclei and their reticular structure, confirm with utmost exactness my earlier accounts. Furthermore, the association of amitosis with an approach toward syncytial conditions also resembles the condition in Eudendrium, as does also the metabolism associated with yolk digestion. I cannot agree, however, with the authors that there is any such relations involved in any of these processes as would bring them into conformity with the theory of Flemming, Ziegler, and others, that they presage degenerative ends. On the contrary, they seem to me to be most intimately associated with the intense metabolism and rapid growth of histogenesis.

It remains briefly to refer to phases of nuclear behavior so characteristic in the cleavage of Pennaria, and to a less extent in Clava. Among these are such features as the highly vesiculate aspects of the nuclei during early cleavage, and the equally anomalous features of clavicular, reniform and dumb-bell shaped nuclei. These facts have been very abundantly confirmed by the several researches of Hargitt, Smallwood, and Beckwith, already cited. Their interpretations, however, differ very widely from my own, and with plausibility and force. It the same time I fail to per- 
ceive that the facts are not quite as clearly within the amitotic mode, and with apparently quite as strong evidence in support of the latter view. Granted the facts of amitosis as a normal process in cytogeny, and this is no longer open to denial, its occurrence along side of mitosis must be allowed. And even where one investigator may find mitosis, another may find both mitosis and amitosis; and this I have shown in the cases already cited, and my results have been confirmed in similar cases by others.

But there is still a further word in this connection. The fact that the nuclear vesicles differ so markedly in size, shape and number is rather difficult to interpret on the basis of mitosis alone. Are these several vesicles derived from single chromosomes, or from several which have fused? If the latter, how shall we correlate the fact with the further fact, admitted by both Smallwood and Beckwith, that it is not essential that these vesicles should fuse between successive mitoses? But how then shall we attempt to explain the assumed exact nuclear equivalents of every mitotic division? But if, on the other hand, it be held that these nuclear vesicles are originally derived from single chromosomes, as seems more likely, how are we to account for the marked diversity of size, number and shape? These queries are not suggested out of any captious spirit, nor on the other hand, as affording an insuperable objection to the interpretations given by these authors, but as more or less clearly pertinent questions which warrant consideration in connection with the problem concerned.

The further assertion of Smallwood in this connection that "the mere shape of the nucleus in Pennaria is no indication of amitosis," may be looked on as somewhat of an evasion of the real issue. I have nowhere made such a claim; but if such were the case it might with pertinence be replied that mere shape is not the point at issue. On the other hand, we are here concerned with particular and anomalous shape, a very different matter. Whether shape has any significance in this relation depends to a marked degree upon the kind of shape. That a reniform, or dumb-bell shaped nucleus 'is no indication of amitosis' may be flatly denied, where it is more or less prevalent. Given such shapes, while 
spheres, spindles, etc., are held to be types of normal nuclei, I think it must be allowed that the burden of proof that the former are but phases of the latter is upon the champions of exclusive mitosis, and thus far the evidence which they-submit has not been convincing.

With the facts herein presented, and the cumulative evidence available from a wide range of observation and authority clearly appreciated, it seems difficult to evade the force of the conclusion which is implied. The writer believes, therefore, that his earlier tentative suggestions concerning amitosis as a mode of nuclear activity is not only not discredited nor disproved by later researches, but is rendered both credible and probable.

\section{SUMMARY}

The main points embodied in the paper may be summarised as follows:

1. Later observations on the development of Pennaria, and including a new species, go clearly to confirm the earlier results, and to show that it is not peculiar to a single species or to a given locality.

2. Observations on the development of Hydractinia echinata also confirm much of that found to occur in Pennaria, including cleavage, ectosarcal features, formation of germ layers, etc.

3. The same may be said in general as to Clava leptostyla. New facts as to certain histogenic aspects seem established, and the significance of the early embryo,- - the morula,- - is emphasized.

4. Concerning the origin and growth of germ cells it becomes more and more certain that the theoretical contentions of Weismann find no warrant in the ontogeny of Coelenterates, and particularly in that of Hydrozoa, the group especially claimed by him.

5. A review of earlier doctrines of homology goes to show that they have been greatly overestimated as criteria of phylogeny. This includes especially the features involved in germ layers, the early hydroid larva, cleavage homology, prelocalization of ger- 
minal areas, etc. The facts of homology and ontogeny as related to phylogeny leave much to be desired ere it will be possible to sustain the earlier conceptions of recapitulation and its enormous implications as to biological philosophy.

6. Amitosis as a factor in cytogenesis is a question of fact. Cumulative evidence from almost every field of cytology goes to show that it is neither rare, nor limited to senile or pathologic conditions of cells or tissues. Its significance in cytogeny is difficult to overestimate. It is not unknown as a factor in embryogeny in any of the great phyla of nature. As a fact it is no less sacred than any other, and must be reckoned with in any final doctrine of development.

\section{BIBLIOGRAPHY}

Alden, Carrie M. 1900 A contribution to the development of Parypha crocea; Biol. Bull., vol. 1, p. 291.

BALfour, F. M. 1885 A treatise on comparative embryology; London, 2nd Edition.

BeCKwith, Cora J. 1909 Preliminary report on the early history of the egg and development of certain hydroids; Biol. Bull., vol. 16, p. 183.

Brooks, W. K. 1886 Life history of North American Hydromedusae; Mem. Bost. Soc. Nat. Hist., vol. 3.

Brooks, W. K. AND Rittenhouse, S. 1907 On Turritopsis nutricula; Proc. Bost. Soc. Nat. Hist., vol. 33, p. 429.

Bunting, Martha 1894 The origin of sex-cells in Hydractinia and Podocoryne, and the development of Hydractinia; Jour. Morph., vol. 9, p. 203.

Child, C. M. 1904 Amitosis in Moniezia; Anat. Anz., Bd. 25, p. 545.

1907a Amitosis as a factor in normal and regulatory growth; Anat. Anz., Bd. 30, p. 271.

$1907 \mathrm{~b}$ Studies on the relation between amitosis and mitosis; Biol. Bull., vol. 12, pp. 89, 175; vol. 13, pp. 138, 165.

Conklin, E. G. 1897 The embryology of Crepidula; Jour. Morph., vol. 13. 1908 The habits and early development of Linerges mercurius; Carnegie Inst., Washington, Pub. No. 103, p. 153.

Glaser, O. C. 1908 A statistical study of mitosis and amitosis in the enteron of Fasciolaria; Biol. Bull., vol. 14, p. 219.

Hargite, C. W. 1900 The natural history and early development of Pennaria tiarella (McCr.); Am. Nat., vol. 34, p. 387.

1904a The early development of Eudendrium; Zool. Jahrb., Bil. 20, p. 257. 
Hargitr, C. W. 1904b The early development of Pennaria tiarella (McCr.); Archiv f. Ent-Mech., Bd. 18, p. 453.

1906 The organization and early development of Clava leptostyla Ag.; Biol. Bull., vol. 10, p. 207.

1908 Notes on the Coelenterates of Woods Hole; Biol. Bull., vol. 14, p. 97 et sèq.

Hargitt, C. W. AND G. T. 1910 Studies in the development of Scyphomedusae; Jour. Morph., vol. 21, p. 217-262.

Haraitt, G. T. 1903 Regeneration in Hydromedusae; Arch. f. Ent-Mech. d. Organismen, Bd. 17, p. 64.

1909 Maturation, fertilization and cleavage of Pennaria tiarella and Tubularia crocea; Bulletin Mus. Comp. Zool. Harvard, vol. 53, no. 3.

Harm, K. 1902 Die Entwickelungsgeschichte von Clava squamata; Zeits.f. wiss. Zool., Bd. 73, p. 115.

Hertwig, O. 1892 Text book of embryology; English trans.,

Hoxley, T. 1849 On the anatomy and affinities of medusae; Phil. Trans. Royal Soc. London, part 2, p. 413.

1859 Oceanic Hydrozoa; Ray Society, London.

Korschelt And Heider 1895 Text book of the embryology of invertebrates; English translation.

Lillie, F. R. 1908 Development of the chick; Henry Holt, New York.

Merejkowsky 1883 Development de la meduse Obelia; Bull.de la Soc. de France.

Metschntкoff, E. 1886 Embryologische Studien an Medusen; Wien.

Montgomery, T. H. 1906 The analysis of racial descent in animals; Henry Holt, New York.

Morgan, LloYd 1891 Animal life and intelligence; Ginn and Company, Boston.

Morgan, T. H. 1897 Development of the frog; Macmillan, New York. 1903 Evolution and adaption; Macmillan, New York.

Owen, R. 1848 Homologies of the vertebrate skeleton, London.

Patterson, J. T. 1908 Amitosis in the pigeon's egg; Anat. Anz., Bd. 32, p. 117.

Rittengouse, S. See Brooks and Rittenhouse.

Roux, W. 1881 Der Kampf der Theile im Organismus.

SMallwood, W. M. 1909 A reëxamination of the cytology of Hydractinia and Pennaria; Biol. Bull., vol. 17.

Weismane, A. 1883 Entstehung der Sexualzellen bei den Hydromedusen. 1889 Essays on heredity; English translation, Macmillan, vol. 1.

1904 Vorträge über Descendzentheorie; English translation, 2 vols. London.

Wilson, E. B. 1884 The development of Renilla; Phil. Trans. Roy. Soc. London, vol. 174 .

1894 The embryological criterion of homology; Biological Lectures, Woods Hole, Boston.

Young, R. T. 1908 The histogenesis of Cysticercus pisiformis; Zool. Jahrb., Bd. 26, p. 183. 


\section{EXPLANATION OF PLATES}

All figures made with the aid of Abbe camera lupida. Those of living eggs in outline only. Details supplied free hand. No attempt has been made to give exact magnification of living eggs, the erratic shapes making this extremely diffcult.

\section{PLATE I}

\section{EXPLANATION OF FIGURES}

1 to 4 Pennaria tiarella. Varying aspects of cleavage in early phases, as a basis for comparing that of Pennaria australis. $p$. protoplasmic connective or strand; a very common feature in these eggs. $x$, a blastomere of second cleavage. In fig. 3 it will be noted that this blastomere segments more rapidly than the lower. This is very common, and continues in fig. 4.

5 to 8 Pennaria australis. Cleavage here resembles in a marked degree that of the preceding species.

9 to $11 \mathrm{~b}$ Hydractinia echinata. An extremely erratic cleavage. In fig. 10 are shown several interesting features, viz. the blastomeres at $x, y, z$. At fig. 11 they are shown in a later stage, in which $x$ and $y$ are just becoming detached. Their later history is shown in figs. 11, $a$ and $b$. 

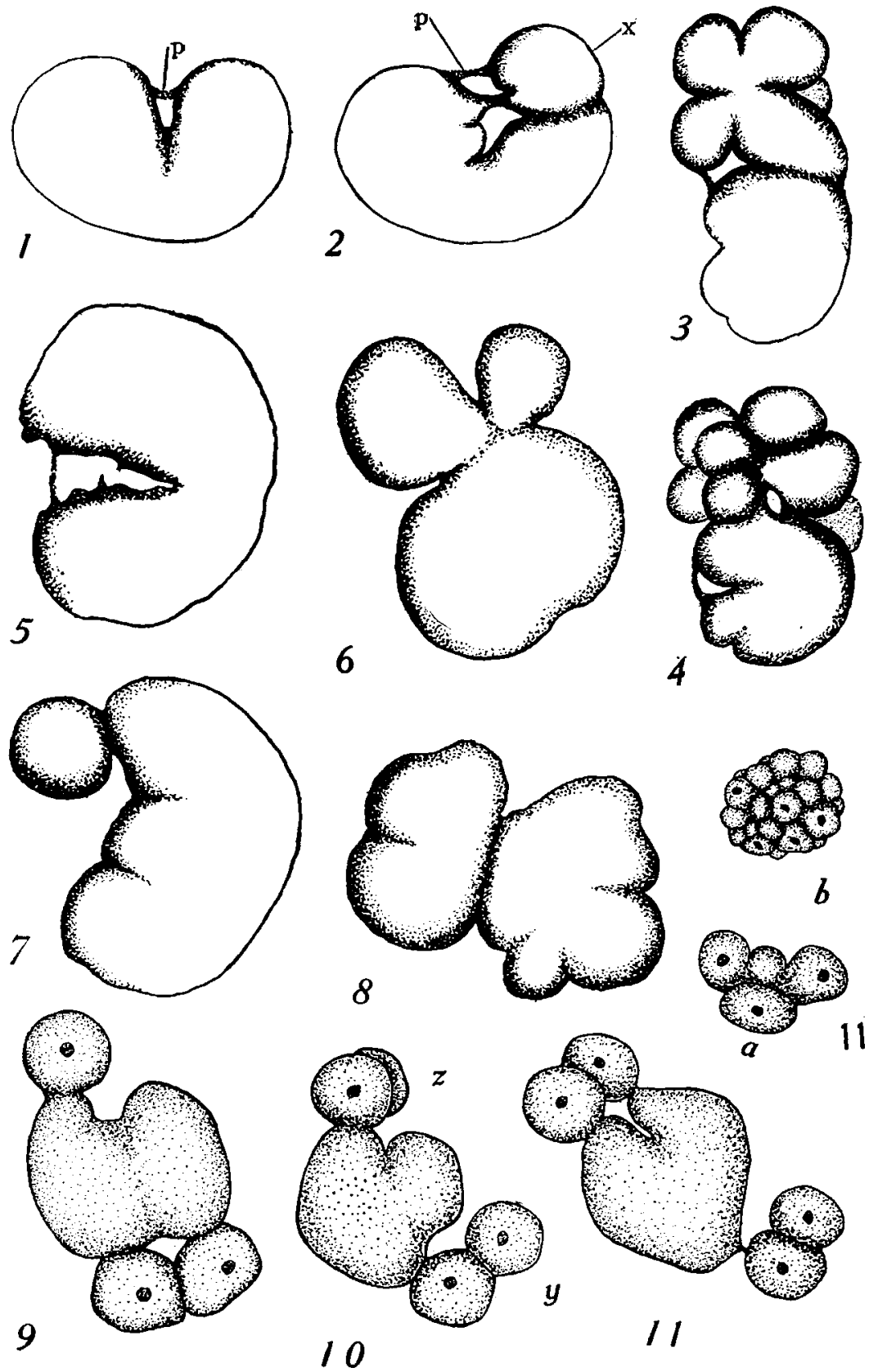

JOURNAL OF' MORPHOLOGY, NOL. 22 , NO. 3 
PLATE 2

\section{EXPLANATION OF FIGURES}

12 to 22 Various phases of cleavage of similar eggs. Figs. 14 to 18 phases of cleavage in a single egg at intervals of ten minutes. The irregular spaces shown are interesting as so-called segmentation cavities. As a matter of fact, they are but aspects of the peculiar ectosarcal and amoeboid activities, and hence absolutely devoid of any blastocoel relations. Such is likewise the case with other similar features in other cases.

19 to 22 Varying phases in the cleavage of another egg, sketched at intervals of fifteen minutes. In these are shown in typical aspects the ectosarcal features more or less common in these eggs. The various strands, papillae, etc. are conspicuous.

12 to 13 Aspects of later cleavage of the egg body shown in figs. 9-11.

23 Gonophore of Clava showing the unusual feature of two perfectly formed and typical germinal vesicles in a single egg. $X$ about 100. 


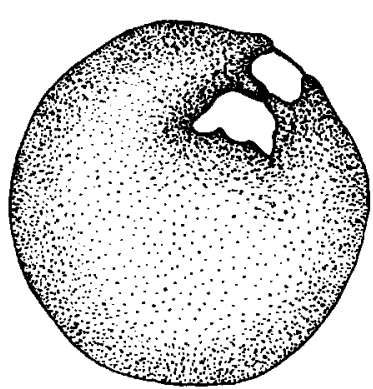

14
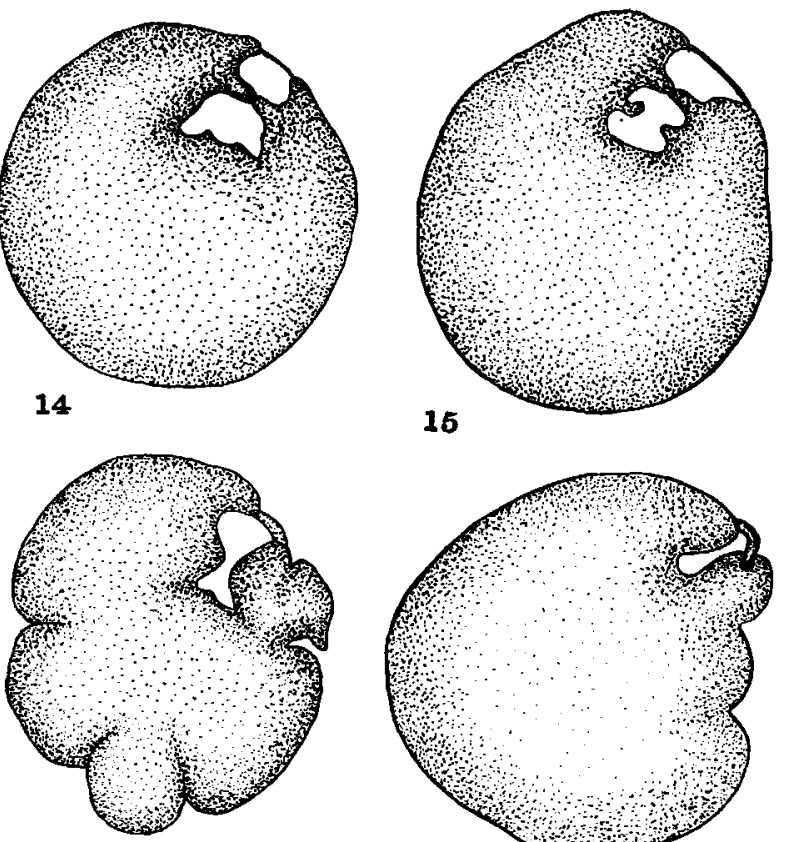

17
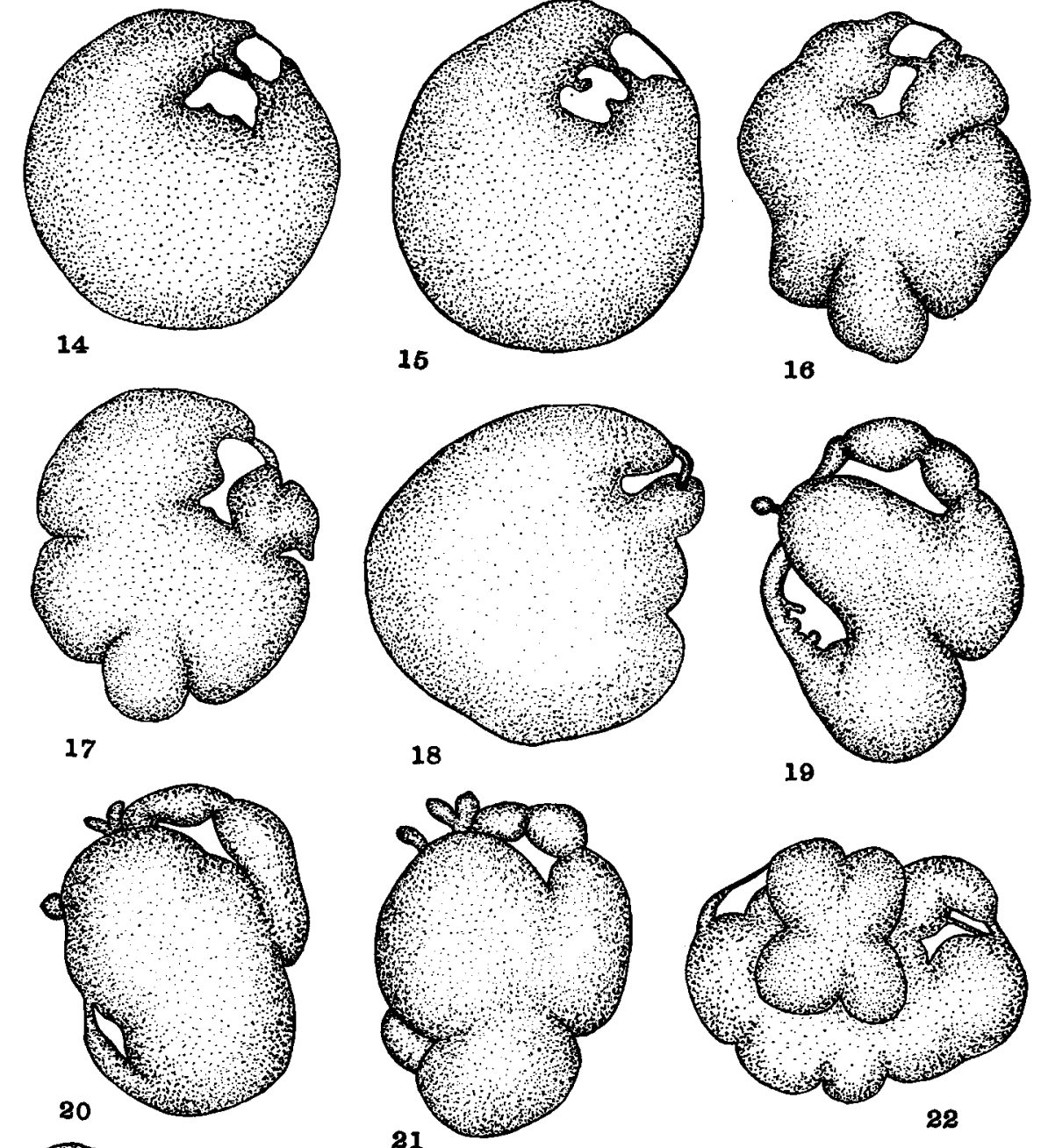

16
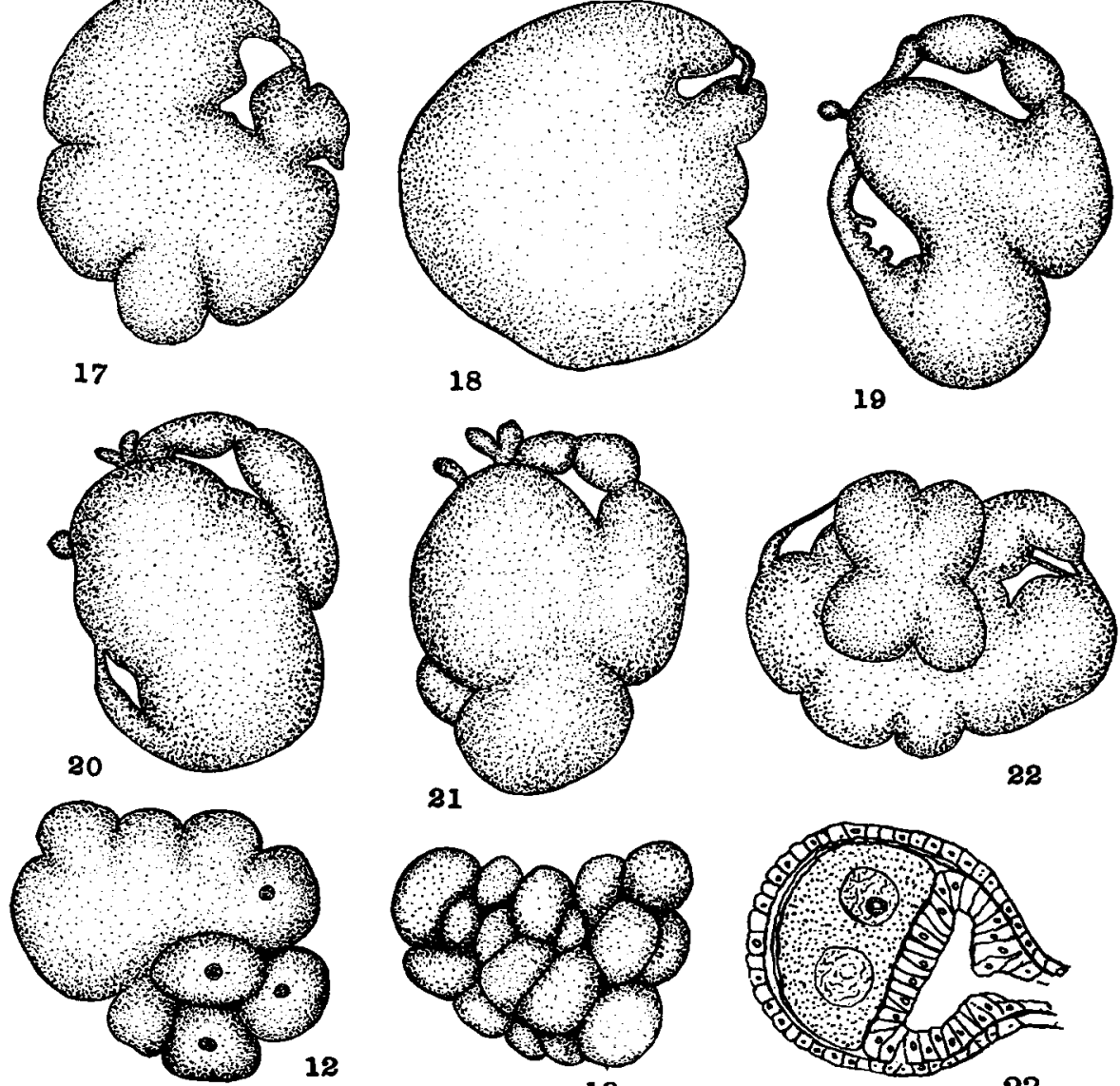

21
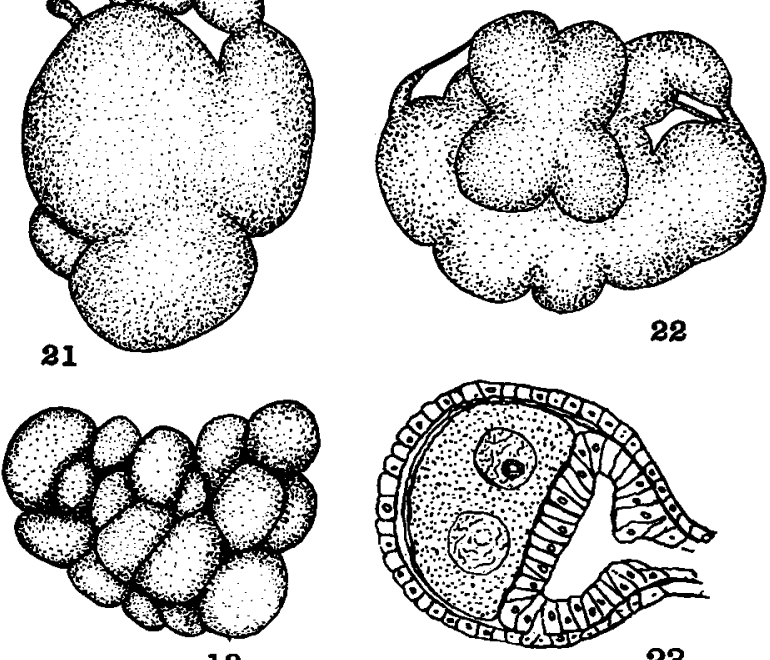

13

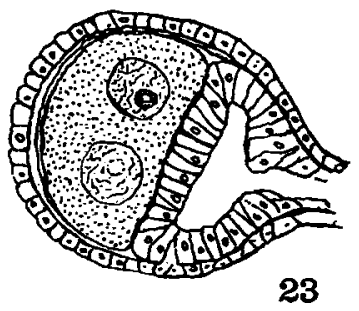

JOURNAL OF MORPHOLOGY, VOL. 22, NO. 3 


\section{PLATE 3}

\section{EXPLANATION OF FIGURES}

24 to 27 Cleavage aspects of Tubularia crocea. (Reproduced from drawinga made by G. T. Hargitt illustrating his paper on early development of Pennaria tiarella and Tubularia crocea. Bull. Mus. Comp. Zoöl., vol. 53, no. 3, by permission.)

24 Cleavage planes which are complete, are more or less vertical, but the equatorial furrows are shown in several of the blastomeres.

25 to 26 Two sections of an egg showing extremely elongated and erratic aspects. The several spaces shown are designated as cleavage cavities. This view I have taken occasion to question in the text of the present paper.

27 So-called blastula stage. This point I have also shown to be a mistaken view. In fact it may be questioned if in any case the term blastula should be applied to early stages of cleavage such as this.

28 Section of an egg of Pennaria tiarella in early cleavage. This is an egg which has shown an unusual regularity in cleavage behavior. $N$ shows a typical resting nucleus, of which several others are shown. At $N^{\prime}$ is shown a nucleus in what seems amitotic cleavage. In this egg are seen also several inner spaces, but which are extremely transient phases.

29 Morula of Clava. The pro-entoderm has been tinted to show the early physiological differentiation of these cells. A discussion of this may be found in the text.

30 Morula of Hybocodon prolifer. As compared with preceding figures of Tubularia, Pennaria, et al.; it shows the same indefinite intercellular spaces, but no distinctive blastocoel. Several nuclei here shown resemble much those of Clava, and appear in some cases in amitotic division.

31 Nucleus of Clava just prior to maturation. The nucleolus is conspicuously vacuolated. Chromatin is in process of fragmentation and dispersal. Stained by picro-hematoxylin which differentiates the yolk beyond mistake, and makes certain the chromatin nature of these granules. $\times 800$.

32 Nucleus of Clava in process of fragmentation and dissolution. First polar body already discharged. Nucleolus in process of collapse; chromatin fragmentation well advanced. Stain as in previous egg. $\times 800$. 


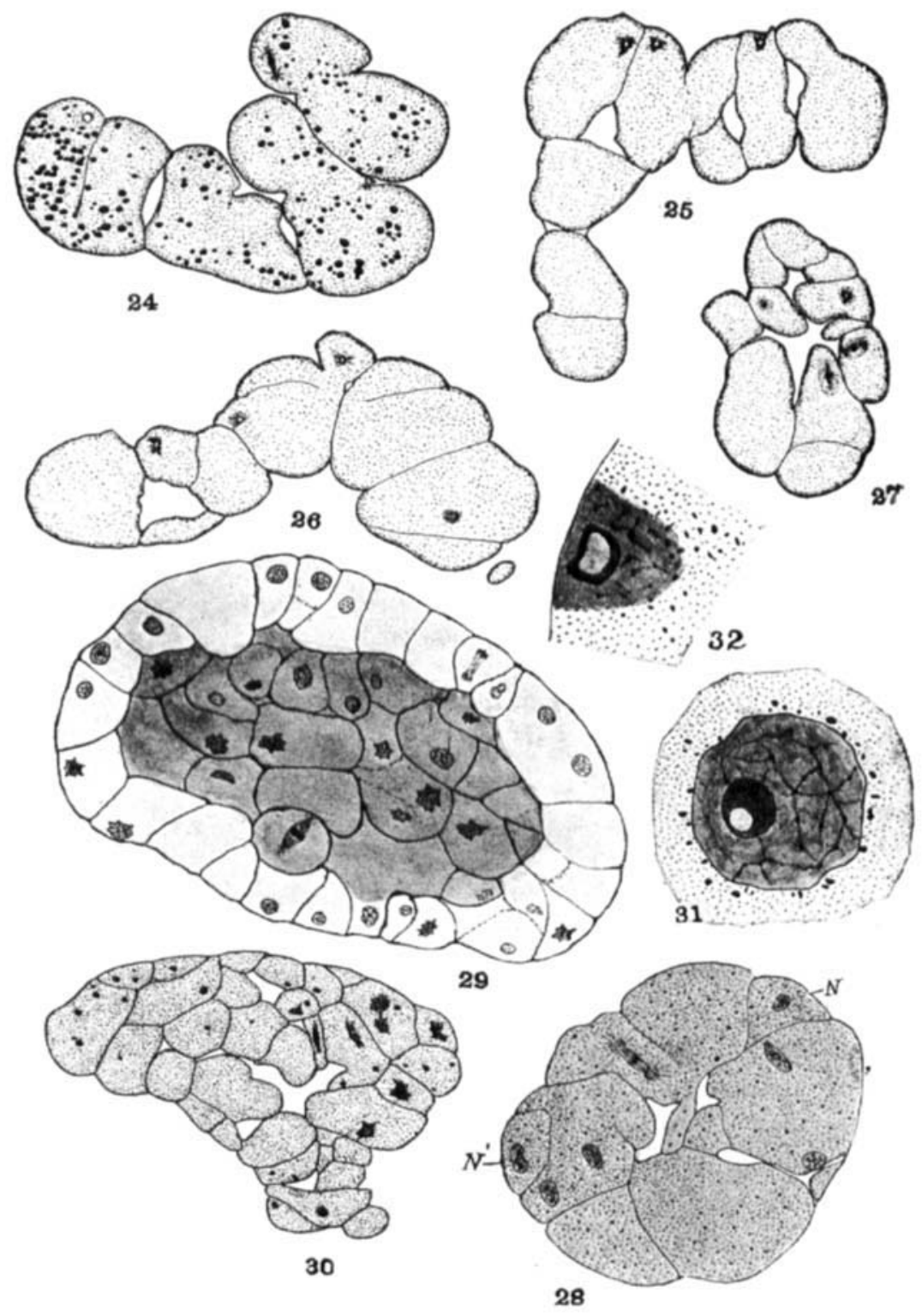

JOURNAL OF MORPHOLOGY, VOL. 22, NO. 3 